\title{
7. MICROFACIES, PALEOENVIRONMENT, AND FACIES-DEPENDENT CARBONATE DIAGENESIS IN UPPER TRIASSIC PLATFORM CARBONATES OFF NORTHWEST AUSTRALIA ${ }^{1}$
}

\author{
Ursula Röhl, ${ }^{2}$ Ulrich von Rad, $^{2}$ and Gunther Wirsing ${ }^{3}$
}

\begin{abstract}
During Ocean Drilling Program Leg 122, $900 \mathrm{~m}$ of Upper Triassic (Carnian to Rhaetian) sediments on the Wombat Plateau (northern Exmouth Plateau) were drilled, an ideal sequence to study eastern Tethyan shallow-water carbonate environments. The early-rift series consists of fluviodeltaic siliciclastics and shallow-marine carbonates including reefal facies.

By comparison with Upper Triassic carbonates of the western Tethys (e.g., Northern Calcareous Alps), several microfacies types could be combined to characteristic facies units: biolithite-facies, different reef talus types, grapestone-oncoid facies, and calcareous algae-foraminifer detritus facies showing the reef-back-reef/fore-reef-lagoon transitions. The Carnian and Norian sequences are dominated by fluviodeltaic sediments that contain many carbonate intercalations. Their frequency and the amount of allochems increase upward in this shallowing-upward system.

Overlying a global sequence boundary at the base of the Rhaetian ("Rhaetian transgression," $215 \mathrm{Ma}$ ), several shallowing-upward cycles from bioturbated wackestones to dolomitic algal bindstones suggest shallow subtidal to intertidal environments. Typical reef development was observed at the platform margin. The limestone-marl alternations of the open-marine shelf grade into local bioclastic and oolitic grainstones, which are the base for the incipient carbonate buildup. Later, calcisponge patch reefs were formed which developed into coral reefs. Several cycles characterize a catch-up carbonate system ("highstand systems tract"). The reef growth ended abruptly with the second sequence boundary, coinciding with a sea-level fall followed by the eustatic latest Rhaetian sea-level rise.

The carbonates were affected by strong diagenesis. Mostly late-diagenetic alteration destroyed earlier diagenetic features. However, several phases can be distinguished which were formed in meteoric-vadose, meteoric-phreatic, marine-phreatic, and burial-diagenetic environments.

The diagenetic successions of the Rhaetian carbonates in Leg 122 suggest that the locally uplifted Wombat Plateau horst was subaerially eroded, probably during the Callovian-Oxfordian.
\end{abstract}

\section{INTRODUCTION}

Sites $759,760,761$, and 764 are located on the Wombat Plateau, a small subplateau, which is separated from the northern Exmouth Plateau by a half graben (Figs. 1 and 2). The sites of Ocean Drilling Program (ODP) Leg 122 were chosen to sample the older Mesozoic record to unravel the late Permian to Late Triassic early rift history, the Jurassic rift-drift transition, and the Cretaceous to Holocene "juvenile" to "mature" ocean history of this sediment-starved passive margin.

We investigated sediment material from these drill sites and dredge material from the Sonne 8 (SO-8) and Rig Seismic 56 $(R S-56)$ cruises to study the early rift history of this margin during the Late Triassic (block-tectonic movements, fluviodeltaic/shallow-water carbonate environments, major Rhaetian carbonate buildup, and early rift volcanism) and the paleoenvironment evolution of a northeast Gondwanan continental margin bordering the southern Tethys Sea. The older Mesozoic history has received little previous attention by deep-sea drilling. The discovery of a 200-m-thick Rhaetian reef complex at Site 764 is the first discovery of Upper Triassic reefal material on the Australian Northwest Shelf.

\footnotetext{
'von Rad, U., Haq, B. U., et al., 1992. Proc. ODP, Sci. Results, 122: College Station, TX (Ocean Drilling Program).

${ }^{2}$ Bundesanstalt für Geowissenschaften und Rohstoffe, Postfach 510153, D-3000 Hannover 51, Federal Republic of Germany.

${ }^{3}$ Geologisches Landesamt Baden-Württemberg, Albertstr. 5, D-7800 Freiburg, Federal Republic of Germany.
}

The discovered Triassic carbonate facies allows the comparison with time-equivalent strata of other east Gondwanan continental fragments, such as the Tethyan Himalaya (cf. Gradstein et al., 1989) and the Timor-Papua New Guinea microplates (cf. Kristan-Tollmann, 1986).

A 900-m-thick composite sequence of Carnian to late Rhaetian age (Haq et al., 1990; Brenner et al., this volume) was recovered from four drill sites. Sites 759, 760, and the lowermost part of Site 761 contain delta-dominated sequences of Carnian-Norian age with some shallow-water carbonate intercalations. The Rhaetian of Site 761 is characterized by an intertidal to subtidal environment with tidal flat, lagoonal, and sand-shoal sediments. The first sponge patch reefs occur here. The Rhaetian of Site 764 reflects the interfingering between lagoonal and reefal facies (von Rad et al., 1989; Haq et al., 1990).

In addition to the samples of Leg 122 drill sites, the dredge material of the Exmouth Plateau area $(S O-8, R S-56)$ contains strata of Upper Triassic and possibly Jurassic age (Liassic? to Callovian) (von Rad et al. 1989). This facies evolution and distribution documents the subsidence of the carbonate platform during the Late Triassic to earliest Jurassic and its destruction into swells and basinal areas (von Stackelberg et al., 1980; von Rad and Exon, 1983; von Rad et al., 1990).

\section{TECTONIC SETTING}

The Wombat Plateau is a small subplateau at the northern edge of Exmouth Plateau with a water depth of about $2000 \mathrm{~m}$. It is separated from the Exmouth Plateau by the deep Wombat halfgraben (Fig. 1). Figure 2 shows a north-south profile across Wombat Plateau with an interpretation that is partly based on seismic reflection data (Williamson et al., 1989; Exon et al., 


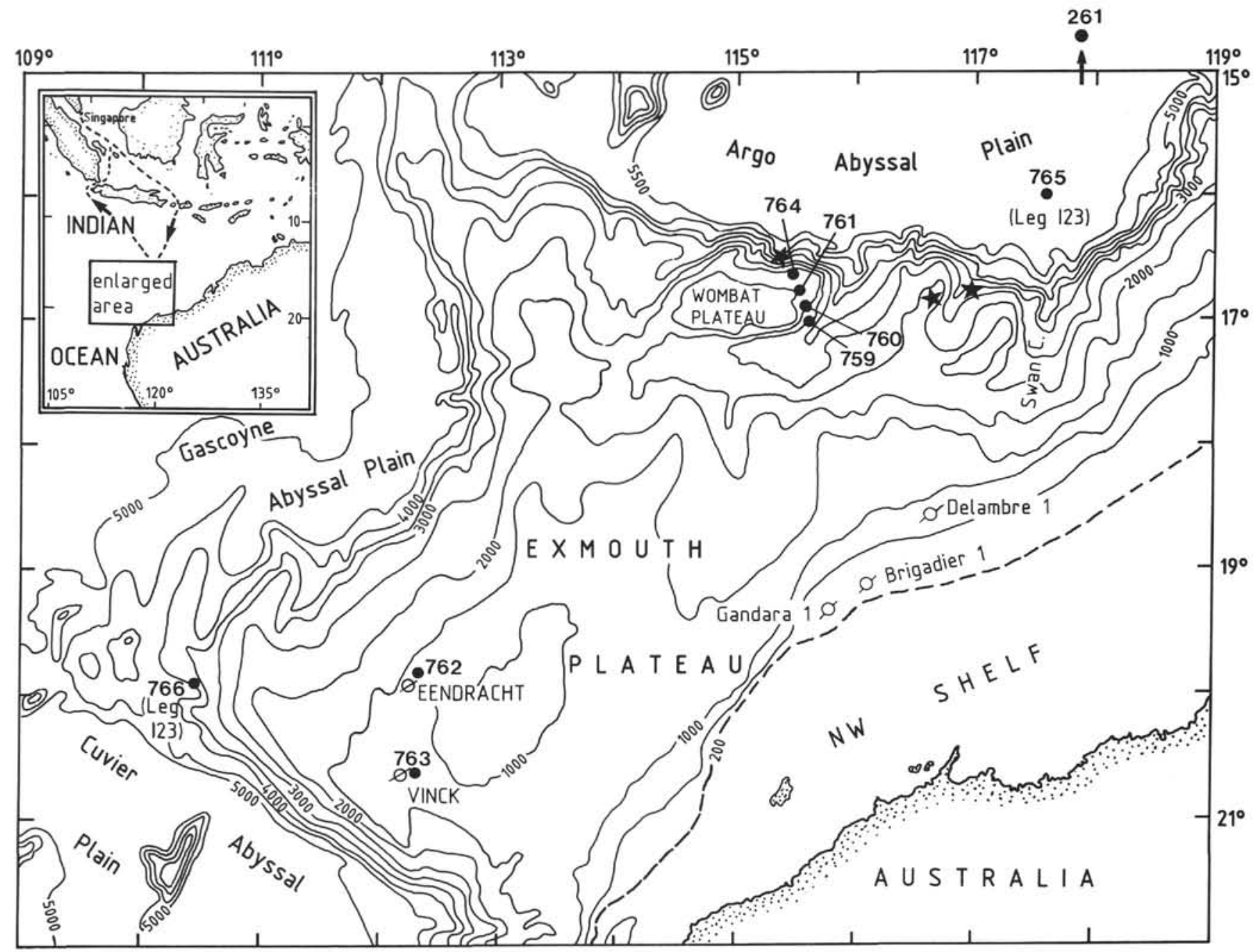

Figure 1. Location map of ODP sites and commercial wells on the Exmouth Plateau and vicinity. The stars show the location of $S O-8$ and $R S-56$ dredge samples as discussed in text. Bathymetry in meters.

1989), partly on ODP drill sites (Shipboard Scientific Party, 1990; von Rad et al., 1989), and partly on dredge results (von Rad and Exon, 1983; von Rad et al., 1990).

The profile shows a conspicuous "post-rift unconformity" within which the entire Jurassic is missing, and which is underlain by Permian to Triassic syn-rift sediments characterized by vertical block faulting. The four ODP sites penetrated a composite thickness of $900 \mathrm{~m}$ of Upper Triassic sediments that due to the northward tilting become progressively younger northward. Unconformities separate this section into lower to middle Carnian, upper Carnian, Norian, and Rhaetian series. The Carnian sediments are $>270 \mathrm{~m}$ thick and consist of prodelta mudstones, deltaic marginalmarine mudstone, and coal, as well as associated shallow-water carbonate intercalations. The Norian sediments are $330 \mathrm{~m}$ to almost $1000 \mathrm{~m}$ thick and consist of several shallowing-upward sequences deposited in shallow-marine, paralic, and coastal plain environments. Seismic profiles show a northward thickening wedge of fluviodeltaic sediments that suggest a progressively more distal (prodelta) character between Sites 760 and 761 . Volcanic rocks occur at different levels in the Upper Triassic sequences below the central Wombat Plateau and along its northern escarpment as shown by seismic records (Williamson et al., 1989). The Rhaetian shallow-water carbonates and part of the Norian strata were eroded south of Site 761. Their thickness ranges from about $170 \mathrm{~m}$ in Site 761 to $240 \mathrm{~m}$ in Site 764. Several reef complexes and associated facies were detected by seismic reflection data on Wombat Plateau and calibrated by Sites 761 and 764 (Williamson et al., 1989; Williamson, this volume).

The Wombat Plateau is a tectonic horst that was faulted by various (Permian? to) Late Triassic rift phases. The horst was then relatively uplifted and subaerially eroded during a major postRhaetian (probably Middle Jurassic, Callovian-Oxfordian) rift phase. The uplift was accompanied by northward "rift flank tilting" that might be explained by isostatic rebound, because the adjacent Wombat half-graben subsided at the same time. The post-rift unconformity is overlain by a thin sequence of $250-\mathrm{m}$ post-breakup sediments: a condensed hemipelagic juvenile-ocean section of Early Cretaceous age, overlain by a eupelagic carbonate section of Late Cretaceous to Cenozoic age (see von Rad et al., this volume).

\section{DEVELOPMENT OF THE CARBONATE PLATFORM AND DEPOSITIONAL ENVIRONMENT}

\section{Methods}

The study began with evaluation of the shipboard report, macroscopic facies analysis using core photos (especially close- 


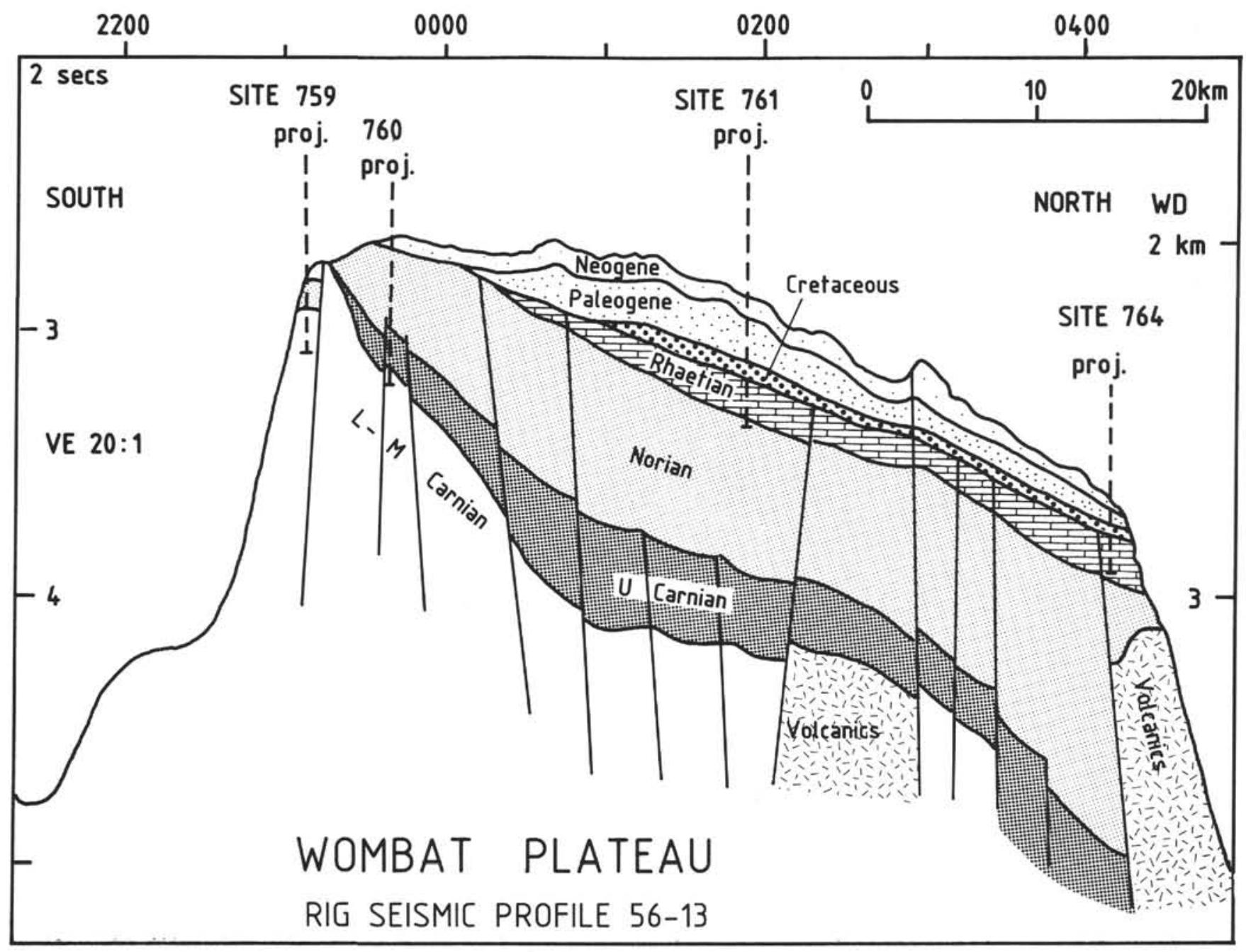

Figure 2. Interpreted multichannel seismic section across Wombat Plateau. The Wombat Plateau is a tectonic horst that was uplifted, tilted, and eroded during a major Jurassic rifting phase.

up photos), and interpretation of natural gamma-ray logs (cf. Boyd and Bent, this volume).

Three hundred and forty-eight thin sections of Leg 122 samples and an additional 54 thin sections of $S O-8$ and $R S-56$ dredge samples were analyzed in detail for microfacies and diagenetic history. This was possible by the creation of a "European Leg 122 thin-section collection," which was jointly used by T. Dumont, U. Röhl, M. Sarti, U. von Rad, T. Wonders, and G. Wirsing. The microfacies and facies zone assignment was necessary for followup diagenetic studies because primary facies variations play a major role in determining the diagenetic pathway. For detailed studies, staining methods (with Alizarin-S), scanning electron microscope (SEM), and cathodoluminescence (CL) were applied to carefully selected samples. Primary biogenic structures that were strongly affected or totally disturbed by diagenetic recrystallization could also be detected by this method.

$\mathrm{X}$-ray diffraction (XRD) analysis verified the mineralogical composition, especially the dolomite content and the $\mathrm{Ca} / \mathrm{Mg}$ ratio, in both calcite and dolomite. X-ray fluorescence analysis (XRF) gave an overview of primary chemical composition and the subsequent diagenetic alteration.

\section{Microfacies of Upper Triassic Shallow-Water Carbonates (Carnian to Rhaetian)}

The comparatively large stratigraphic (Carnian to Rhaetian) and facies range (estuarine lagoon-shoal-shelf-lagoon-reefopen-marine shelf) of drilled and dredged carbonates allows the determination of many microfacies types (MFT). We used and extended the Dunham (1962) classification, which is very valuable for genetic interpretations.

Twenty-five main types of carbonates were distinguished, based on the kind and amount of main biogenic and abiogenic allochems. In Table 1 each microfacies type is listed and compared with the depositional environment. Photomicrographs of thin sections are shown in Plates 1 and 2. An extensive optical study of the microfacies types was the first step of our investigations. Their detailed characterization is published in a companion paper (Röhl et al., 1991).

The main microfacies types are lagoonal wackestones and packstones, and grainstones characteristic of shoals. Fragments of pelecypod and brachiopod shells and peloids are the main 
Table 1. Microfacies types, facies units, and facies zones identified at Sites 759, 760, 761, and 764.

\begin{tabular}{|c|c|c|c|}
\hline & 1. Mudstone & & \\
\hline $\begin{array}{c}\text { Foraminifers- } \\
\text { detritus } \\
\text { facies }\end{array}$ & $\begin{array}{l}\text { 2. Bioturbated wackestone } \\
\text { 3. Foraminiferal wackestone } \\
\text { a. Triasina predominant } \\
\text { b. Involutinidae predominant } \\
\text { c. Duostominidae predominant } \\
\text { 4. Wackestones s.l. } \\
\text { a. peloidal wackestone } \\
\text { b. coated grain wackestone } \\
\text { 5. Ostracode-rich wackestone } \\
\text { 6. Echinodermal wackestone } \\
\text { 7. Skeletal wackestone }\end{array}$ & & $\begin{array}{l}\text { (Estuarine) } \\
\text { Lagoonal } \\
\text { facies } \\
\text { (Shelf) }\end{array}$ \\
\hline \multirow{3}{*}{$\begin{array}{l}\text { Foraminifers- } \\
\text { calcareous algae } \\
\text { and } \\
\text { crinoid facies }\end{array}$} & $\begin{array}{l}\text { 8. Foraminiferal packstone } \\
\text { a. Involutinidae predominant } \\
\text { b. Triasina predominant } \\
\text { 9. Peloidal packstone }\end{array}$ & Lagoon & \multirow{3}{*}{$\begin{array}{c}\text { Transition } \\
\text { facies }\end{array}$} \\
\hline & $\begin{array}{l}\text { 10. Skeletal packstone } \\
\text { (to grainstone-partly } \\
\text { grapestone facies) } \\
\text { 11. Echinodermal packstone } \\
\text { 12. Codiacean wackestone to packstone }\end{array}$ & Open-marine & \\
\hline & $\begin{array}{l}\text { 13. Skeletal floatstone } \\
\text { 14. Coral/sponge floatstone }\end{array}$ & Reefal debris & \\
\hline $\begin{array}{l}\text { Oncolitic- } \\
\text { oolitic facies }\end{array}$ & $\begin{array}{l}\text { 15. Foraminiferal grainstone } \\
\text { 16. Coated grain grainstone } \\
\text { 17. Oolitic grainstone } \\
\text { 18. Oncolitic grainstone } \\
\text { 19. Dasycladacean grainstone } \\
\text { 20. Codiacean grainstone } \\
\text { 21. Peloidal grainstone } \\
\text { 22. Skeletal grainstone s.l. } \\
\text { to rudstone }\end{array}$ & & $\begin{array}{l}\text { Carbonate } \\
\text { sand-shoal } \\
\text { facies }\end{array}$ \\
\hline $\begin{array}{l}\text { Biolithite } \\
\text { facies }\end{array}$ & $\begin{array}{l}\text { 23. Algal bindstone } \\
\text { 24. Boundstones } \\
\text { a. coral- } \\
\text { b. sponge- } \\
\text { c. sponge/hydrozoan } \\
\text { 25. Boundstones and framestones } \\
\text { (sponges and corals) }\end{array}$ & & $\begin{array}{l}\text { Reefal } \\
\text { facies }\end{array}$ \\
\hline
\end{tabular}

Note: Modified and extended version of the textural classification by Dunham (1962).

allochems, followed by coral and calcisponge fragments and coated grains s.l. (simple ooids, normal ooids, and oncoids).

Figure 3 illustrates as histograms the distribution of the 25 microfacies types in the four investigated ODP sites. At Sites 759 and 760 grainstones predominate. At Site 764 wackestones/packstones and boundstones are the main microfacies types. Site 761 takes a transitional position between these two end-members, although the maxima are found in the group of skeletal wackestones and peloidal packstones indicating a shelf-lagoonal environment.

An overview of all the important microfacies observations proved to be very helpful for the correlation of beds of the four ODP sites on the Wombat Plateau (see the following two sections). This method facilitates the determination of characteristic facies units. These are (1) detritus-mud facies, (2) calcareous algae-foraminiferal facies, (3) oncoid-grapestone facies, (4) biolithite facies, and (5) crinoidal limestone facies, which we will characterize in the following chapter.

\section{Carbonates in the Fluviodeltaic-Dominated Series of Carnian and Norian}

For detailed descriptions and interpretations of the Carnian and Norian siliciclastics, see Shipboard Scientific Party (1990) and Ito et al. (this volume).

The delta-dominated sequences in Sites 759 and 760 of Carnian and Norian age include several shallow-water carbonate intercalations (Fig. 4). Due to the shallowing of the depositional environment from bottom to top at each site, the frequency and percentage of components increase. The natural gamma-ray log in Figure 5 confirms the amount and position of carbonates in Site 759 by the negative spikes. These reflect low potassium and thorium and, therefore, a low shale content of the carbonate-rich section.

The limestone intercalations are partly interpreted as storm deposits derived from a marginal carbonate platform. They show characteristic features such as erosive bases and grading of allochems, which indicate a high-energy event. The limestones commonly contain a large amount of quartz grains, large, broken pelecypod shells, and crinoid fragments. Other limestone types are bioclastic sands, containing fragments of calcareous algae, foraminifers (Pl. 1, Fig. 6), oncoids, and ooids, which were washed together on shoals in front of river deltas. The biogenic allochems were partly derived from algal mats or patch reefs in areas within intradeltaic lagoons or interdistributary bays which were protected from siliciclastic dilution (see "Facies Model" section, this chapter).

On the basis of the carbonate microfacies types and their vertical distribution, we divide the carbonate intercalations of Sites 759 and 760 into three main sections which may be subdivided into subsections (Fig. 4). From base to top we distinguish (1) a calcareous algae-dominated facies with oolites (Cores 122759B-23R to $-19 \mathrm{R} ; 122-760 \mathrm{~B}-22 \mathrm{R}$ to $-20 \mathrm{R}$, member 1 ), (2) an oolitic-/oncolitic-dominated facies including dolomites and floatstones bearing coral or sponge fragments (Cores 122-759B-16R 


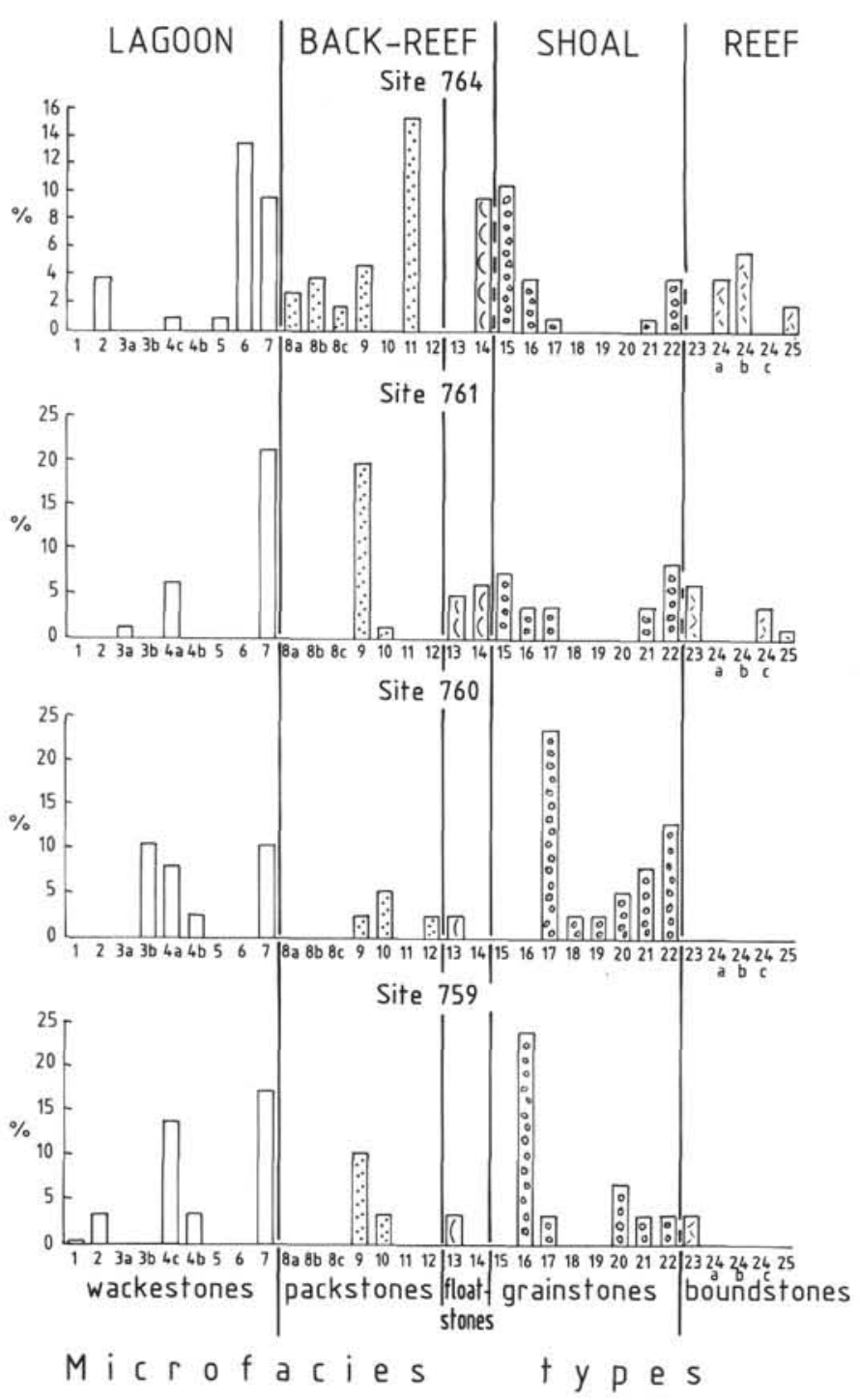

Figure 3. Distribution of microfacies types (MFT) within the four investigated Sites 759 to 761 , and 764 . The specific microfacies are identified by number above their dominant rock type. $Y$-axes represent the amount of distinct microfacies types (\%) in relation to all investigated samples. The Carnian and Norian Sites 759 and 760 show their maxima within the grainstone group. The Rhaetian of Site 764 is dominated by wackestones, packstones, and boundstones. The Rhaetian of Site 761 has a transitional position.

to $-12 \mathrm{R} ; 122-760 \mathrm{~B}-17 \mathrm{R}$ to $-15 \mathrm{R}$, member 2 ), and (3) an oolitic-/ algal-stromatolitic-dominated facies (Cores 122-759B-11R to -7R; 122-760B-14R to -7R, member 3).

Site 760 is made up of limestones, which indicates better-ventilated areas than those of Site 759. This observation agrees with the general paleogeographic conception of a more nearshore position of Site 759 compared with Site 760.

The calcareous algae-dominated facies with oolites consists of codiacean float- and grainstones (MFT 20, Pl. 2, Fig. 3), dasycladacean grainstones (MFT 19, Pl. 1, Fig. 4), coated-grain grainstones (MFT 16), and subordinate skeletal wackestones and floatstones with codiaceans (MFT 12 and 13). The oolitic-oncolitic-dominated facies contains coated-grain grainstones (MFT 16), oolitic grainstones (MFT 17), and oncolitic grainstones (MFT 18, Pl. 2, Fig. 1). At Site 759, the oncolitic grainstones interfinger with dolomitic mudstones. At both drill sites we observed a characteristic skeletal wackestone to floatstone (Cores 122-759B$13 \mathrm{R}$ and 122-760B-14R) with large coral fragments (MFT 14). The oolitic-/algal-stromatolitic facies of the third limestone unit includes, from bottom to top, skeletal to oolitic grainstones (MFT 17 and 22), dolomitic wackestones (PI. 1, Fig. 1), and quartz-bearing oolitic grainstones (MFT 17).

The somewhat thick, lithologically similar sections at both sites, which contain correlatable limestone series, are not interpreted to be the result of strong shifting of the facies zones. We correlate the Carnian and Norian of Sites 759 and 760 according to the kind and distribution of the microfacies of intercalated limestones (Fig. 4). In general, the palynological zones (Brenner et al., this volume) agree with our correlation of Sites 759 and 760. But his "Carnian and Norian"/"Norian" boundary crosses our lithostratigraphic correlation. This might be due to reworking of palynomorphs by repeated reworking of the terrigenous, siliciclastic sediments by storm-induced currents. Because the carbonate types, which are partly storm deposits, preserve their characteristic composition (e.g., ooids and calcareous algae) from their respective source area, we used them as "marker beds."

The change from a deltaic sandstone to an oolitic limestone in Cores $122-759 \mathrm{~B}-24 \mathrm{R}$ and $-23 \mathrm{R}$ was interpreted as a sequence boundary by the Shipboard Scientific Party (1990). This sequence boundary is related to a rifting event within the Carnian.

The sandstone unit in Cores 122-760B-19 and -18R was dated within the Carnian to Norian section in Site 760 (Brenner et al., this volume). This characteristic unit contains a conglomeratic horizon including volcanic rock fragments at its base, which indicate a "rifting event" (Fig. 6). Tectonic uplift caused an increase of the relief that produced tectonic breccias. The uplift/subsidence movements were accompanied with volcanic activities during this interval. The same conglomeratic sandstone layer was found in Site 759 (see Shipboard Scientific Party, 1990). Our detailed lithostratigraphic correlation of the two sites suggests a time gap at Sites 759 and 760 within the latest Carnian to early Norian (Fig. 4): the limestones recovered in Core 122-759$19 \mathrm{R}$ are missing from Site 760 , but all carbonate beds under- and overlying this section could be identified in both sites. We therefore assume that the equivalent sections of Cores 122-759B-19R to $-17 \mathrm{R}$ were eroded Site 760 .

In Figure 6 the Upper Triassic lithological columns of Sites 759 and 760 are shown with first- and second-order cycles. These cycles are produced by a cyclic change of siliciclastic and carbonate grain-size distributions. The second-order cycles are mainly 10 -m-scale, coarsening-upward units. Several of these first-order cycles can be combined to 30 - to 50 -m-scale second-order cycles (fourth- or fifth-order cycle according to Vail et al., 1977). Such coarsening- and shallowing-upward cycles document the common facies shift within a delta-dominated to marginal marine environment (cf. Einsele, 1982). However, we cannot exclude an influence of small-scale eustatic sea-level changes.

This first approach of a sequence analysis bears out the theory of the important intra-Norian tectonic (rifting) event (see above). The accompanying higher subsidence rate caused a local increase of the relative sea level. The result was a reversal of the normal coarsening-upward cycle series of the deltaic/marginal marine environment being replaced by fining-upward cycles of an openmarine shelf (Fig. 6).

The Norian of Site 761, Core 122-761-33R (Unit VI), consists of black silty claystone with coal. It is interpreted as having been deposited in a swampy fluviodeltaic environment ("coal-measure sequences").

\section{Rhaetian Reefal and Lagoonal Facies}

The early Rhaetian transgression is documented by a sequence boundary at Site 761 (Fig. 7). This site is characterized by an 


\section{SITE 759}

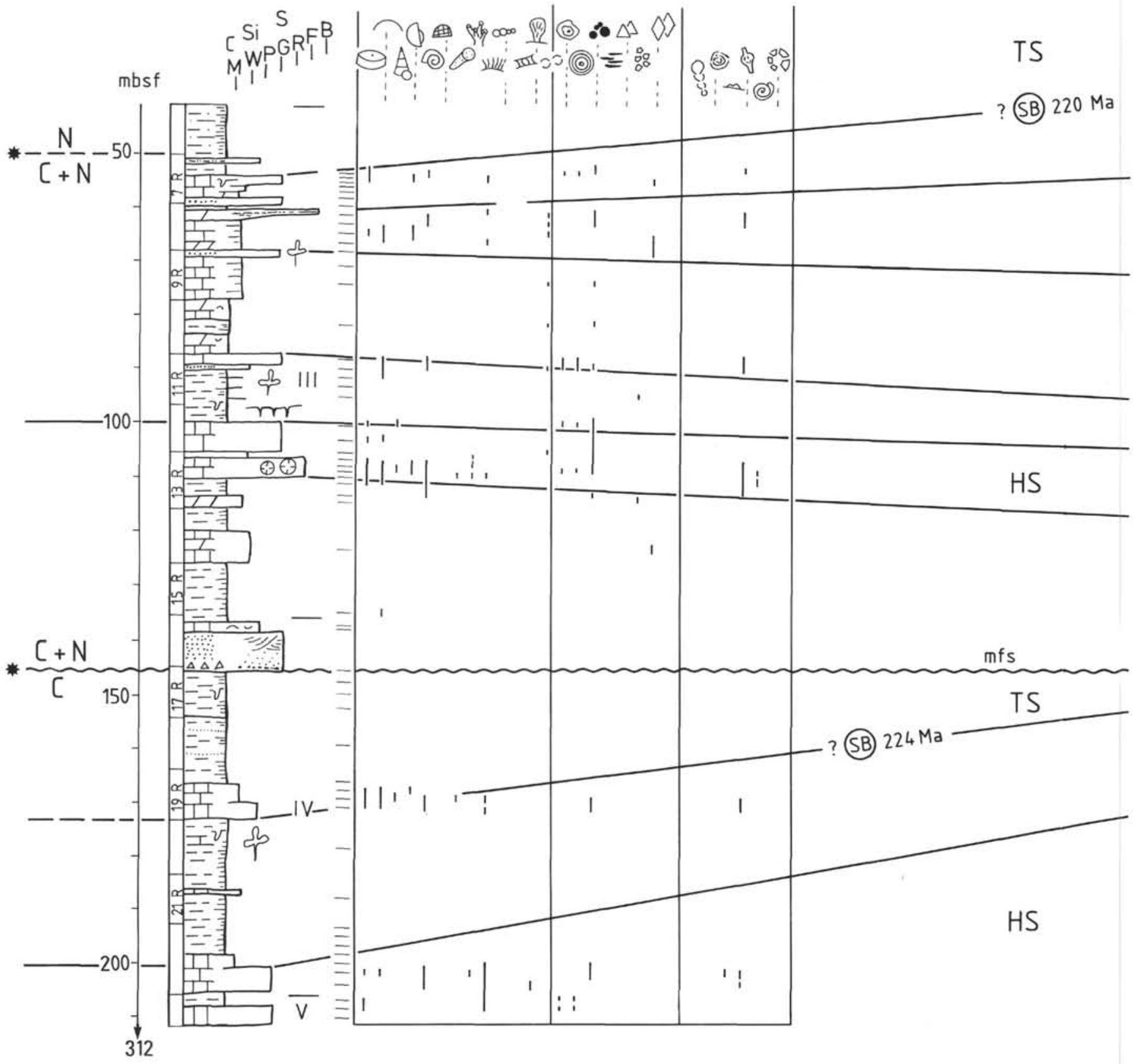

Figure 4. Parallelization of the carbonate-bearing parts of Sites 759 and 760 according to the microfacies and sequential evolution of limestones. The biogenic and abiogenic allochems, as well as some diagenetic features are plotted against the lithological column. For further explanations, see text. The letters $\mathrm{M}-\mathrm{B}$ refer to rock types mudstones to boundstones; $\mathrm{C}=$ claystone, $\mathrm{Si}=$ siltstone, $\mathrm{S}=$ sandstone. $\mathrm{HS}=$ highstand systems tract, $\mathrm{TST}=$ transgressive systems tract, $\mathrm{MFS}=$ maximum flooding surface, $\mathrm{SB}=$ sequence boundary; $\mathrm{mbsf}=$ meters below seafloor. The numerals III, IV, V, VI, and VII reflect the shipboard lithological units (Haq et al., 1989). The star in combination with $\mathrm{C} / \mathrm{C}+\mathrm{N}$ corresponds to the Carnian to Carnian and Norian boundary, and the $\mathrm{C}+\mathrm{N} / \mathrm{N}$ to the Carnian and Norian to Norian boundary of Brenner et al. (this volume). Legend for this figure is on page 8 . 
SITE 760



Figure 4 (continued). 


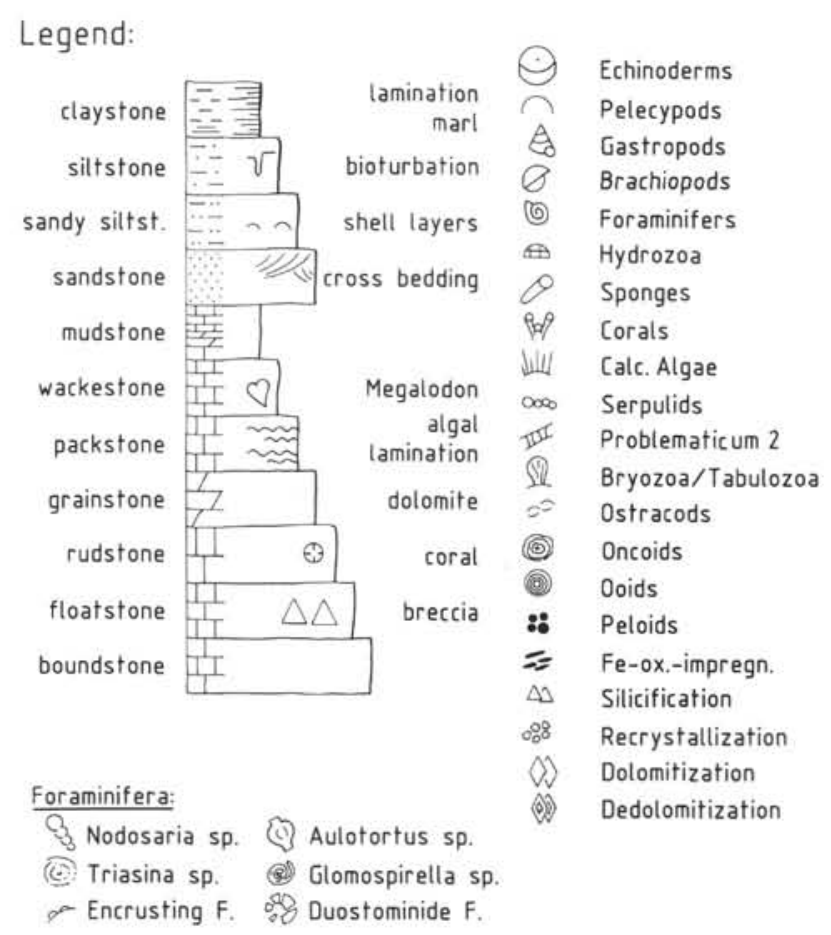

Figure 4 (continued).

intertidal carbonate flat to shelf-lagoon environment with a transition to sand-shoal facies associated with patch reefs in a lagoonal setting. Site 764 contains typical features of reef development with several lagoonal/reefal cycles.

In Figure 8 the lithological columns are compared with the induced gamma-spectroscopy downhole log (GST, normalized content of $\mathrm{Si}, \mathrm{Ca}$, and $\mathrm{Al}$; Russell and Ogehenejobo, 1984). At both sites the upward decrease of terrigenous material is indicated by the decreasing normalized $\mathrm{Si}$ content from the base to the middle part of the sites. The upper reef cycle (coral/calcisponge patch reef at Site 764,80 meters below seafloor, or mbsf; algal laminite at Site 761, $280 \mathrm{mbsf}$ ) reflects the renewed larger terrigenous input due to the following uppermost Rhaetian transgression, which is documented at Site 764. Two Si peaks in both sites confirm the correlation due to the microfacies types.

\section{Stratigraphic Evolution of the Drill Sites}

For a better correlation with the results of other papers in this volume we decided to retain the shipboard lithological units shown in Figures 7 and 9 (see Shipboard Scientific Party, 1990, Sites 759-761 and 764, their fig. 2). We characterized each of them in more detail and subdivided them using the methods of carbonate-petrography (Flügel, 1982; Folk, 1959, 1962; Wilson, 1982).

\section{Site 761}

Unit VB (399.3-428.4 mbsf). The base of the Rhaetian section at Site 761 is a sharp-based, intraclast-rich packstone grading into a quartz sand layer with large biogenic fragments (Fig. 7). It may represent a transgressive subtidal sand wave deposited on underlying claystones and coals of a delta plain facies (Norian, Unit VI, with low water depth) and followed by the deposition of dark, laminated claystones with intercalations of crinoidal limestones (Rhaetian, Unit VB). These crinoidal limestones are probably deposits of a shelf-lagoonal environment. Their allochems were derived from better oxygenated areas with a rich benthic and sessile fauna. We found skeletal grainstones (MFT 22), skeletal

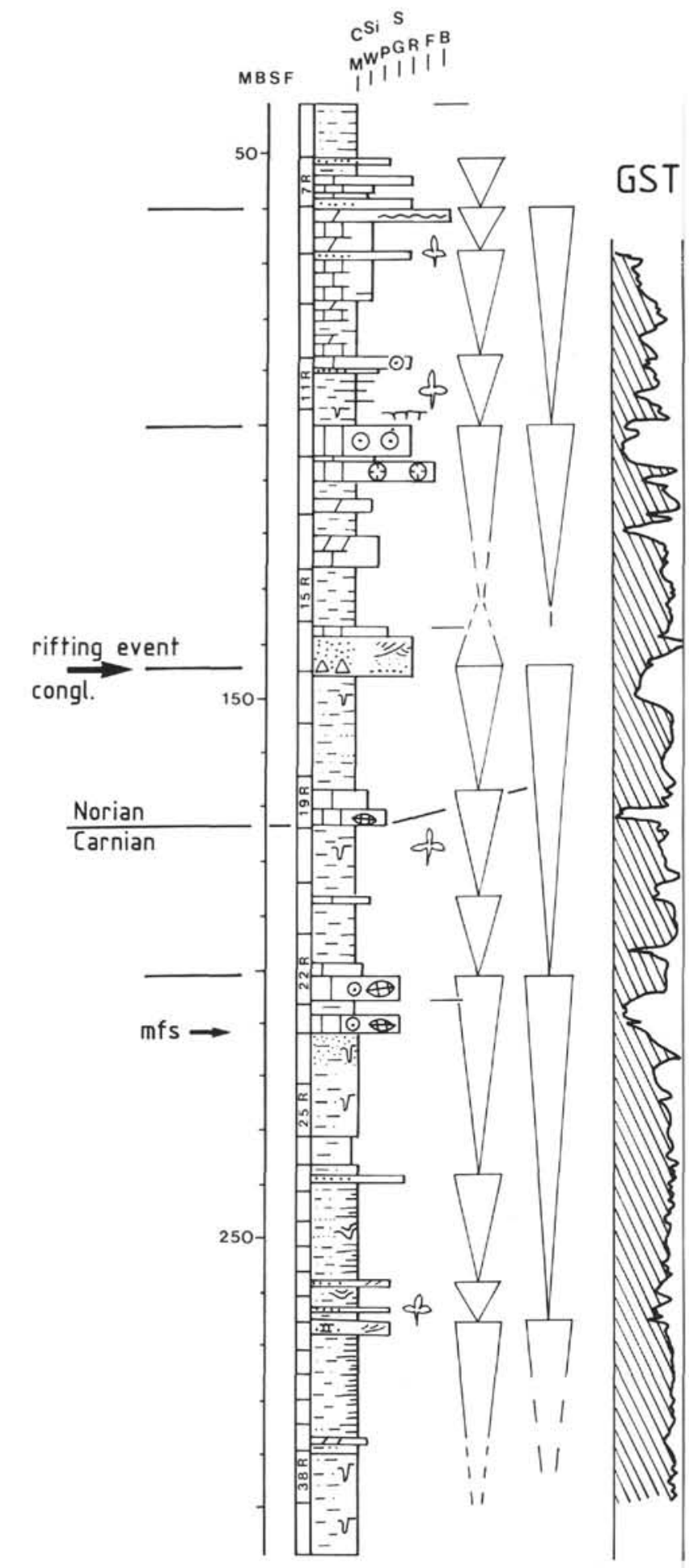

Figure 5. The negative peaks of the natural gamma-ray $\log$ (GST = gamma-ray spectroscopy tool) correlate well with the positions of limestones within Site 759. The letters $\mathrm{M}-\mathrm{B}$ correspond to mudstones to boundstones. $\mathrm{C}=$ claystone, $\mathrm{Si}=$ siltstone, $\mathrm{S}=$ sandstone, $\mathrm{MFS}=$ maximum flooding surface, and $\mathrm{mbsf}=$ meters below seafloor. See Figure 4 for legend.

packstones (MFT 10), coated-grain grainstones (MFT 16), and coral/calcisponge floatstones (MFT 14). They contain pelecypod and brachiopod fragments, some foraminifers, dasycladaceans, gastropods, sponge, and coral fragments, and rare coated grains. Core $122-761$ C-32R also includes rare quartz, feldspar, and vol- 


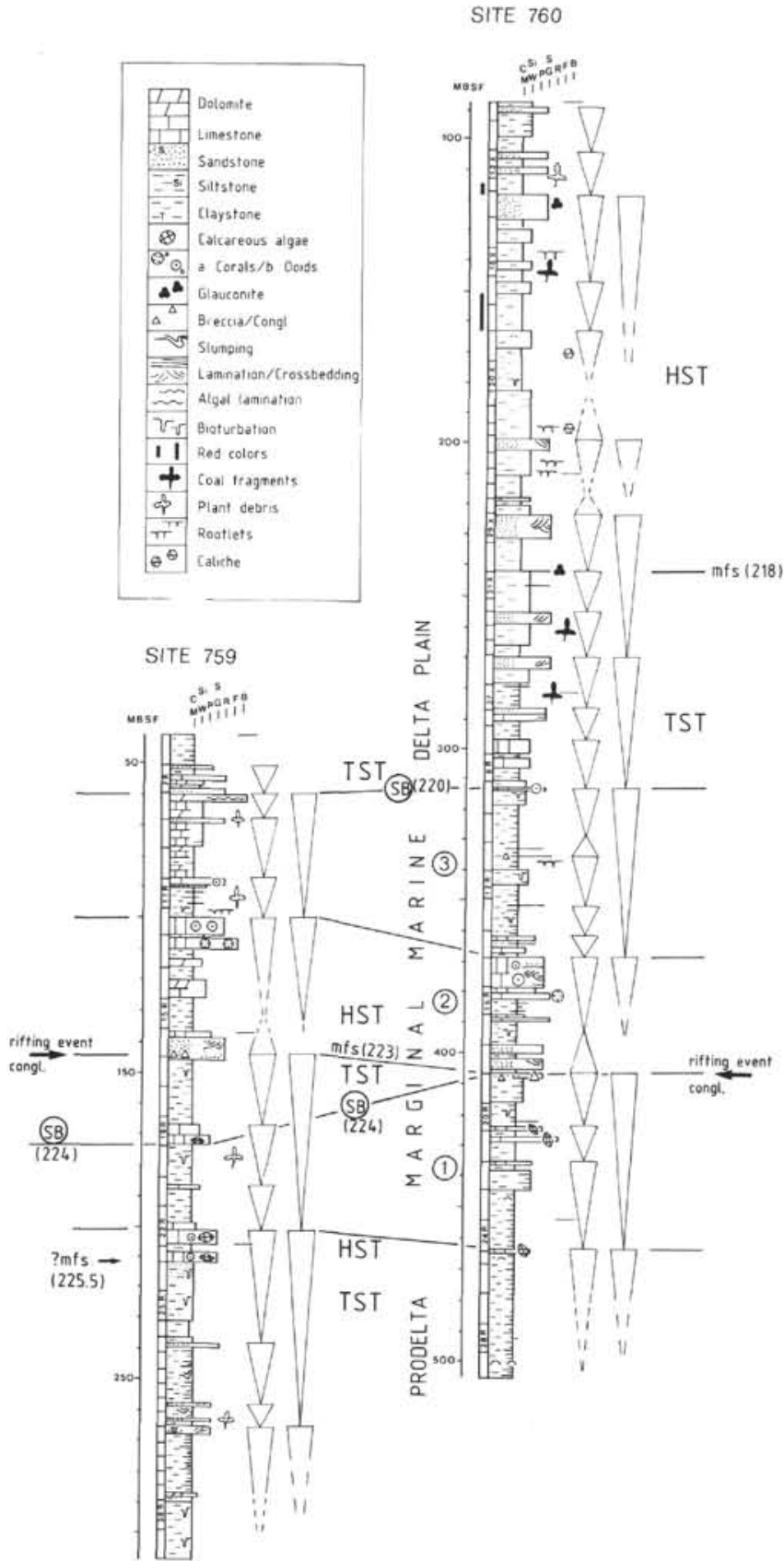

Figure 6. Coarsening-upward cycles of different orders at Sites 759 and 760. Note that the event at $145 \mathrm{mbsf}$ at Site 759 and at $408 \mathrm{mbsf}$ at Site 760 interrupted the normal trend. The Camian/Norian boundary crosses the sequence because the event eroded parts of Site 760. HST = highstand systems tract, $\mathrm{TST}=$ transgressive systems tract, $\mathrm{SB}=$ sequence boundary. $\mathrm{M}-\mathrm{B}$ correspond to mudstones to boundstones, $\mathrm{C}=$ claystone, $\mathrm{SI}=$ siltstone, $\mathrm{S}=$ sandstone, and $\mathrm{mbsf}=$ meters below seafloor.

canic rock fragments. The facies association and the composition of other biogenic allochems (coral and calcareous algal fragments, which are parautochthonous at best) suppose the assumption of shallower water depths. The alternation with dark, laminated claystones suggests a restricted, oxygen-depleted environment with allochthonous limestone intercalations. Very significant is the upper part of Unit VB (Core 122-761C-30R), which is made up of coral-algal (corallinacean) or sponge bound- to floatstones. This marks the first development of a patch reef in a lagoonal environment in sediments recovered at this site. Compared with the overlying units, the microfacies types of this unit are characterized by the large amounts of coral, algal, and sponge fragments, the frequency of brachiopod shell fragments and rare peloids. A typical feature of the carbonate sequences at this drill site is strong dolomitization, accompanied by the typical iron-oxide enrichment (reddish colors; see "Dolomites and Dolomitization" section, this chapter).

Unit VA (332.3-399.3 mbsf). This unit represents a marl/limestone alternation. Skeletal wacke- to packstones with echinodermal debris (mostly crinoids) (MFT 6, 7, 10, and 11) characterize the lower limestone-dominated part of the succession (Core 122$761 \mathrm{C}-29 \mathrm{R}$ to $-27 \mathrm{R})$. At the top we found skeletal grainstones (MFT 22). This sequence reflects a coarsening-upward series and leads to the open-shelf environment of the middle and lowerupper part of Unit VA (Cores 122-761C-26R and -24R), where mudstones and marlstones alternate with partly bioturbated wackestones and packstones. These contain mainly pelecypod and ostracode shells, echinoderm fragments, and framboidal pyrite.

The uppermost section of Unit VA begins with a marker horizon (Core 122-761C-23R) which consists of wackestones to floatstones with fragments of calcareous algae (MFT 13/14). Oolitic packstones to grainstones were also found.

Unit IV (259.5-332.3 mbsf). Core 122-761C-22R contains mainly wackestones to packstones of MFT 7 with an increase in peloids. Foraminifers are mainly nodosariids. The obvious macroscopic change from limestone/marl alternations of the open shallow-marine shelf to the shallow-marine lagoonal environment is also verified by the distribution of biogenic allochems (Fig. 7). From Core 122-761C-21R to -18R, foraminifers and peloids mark the microfacies types (e.g., MFT 3-foraminiferal wackestones, MFT 9-peloidal packstones, sometimes also MFT 22-grainstones). In addition to the dominance of different foraminifers and peloids, the small percentage of pelecypod and echinoderm fragments is remarkable in comparison to the lower and upper parts of the site.

Cores $122-761 \mathrm{C}-16 \mathrm{R}$ to $-15 \mathrm{R}$ (and Core 122-761A-33X) form the most characteristic horizon in Unit IV. Several shallowing-upward cycles form bioturbated wackestones (MFT 2) via foraminiferal peloidal wackestones (MFT 3A with high Triasina contents, and MFT 4A, shallow-subtidal, lagoon) to dolomitic algal bindstones (MFT 23, intertidal; Fig. 10). Sheet cracks, mud cracks, and keystone vugs (Pl. 1, Fig. 3) in peloidal horizons (sometimes within the uppermost part of the cycles) indicate subaerial exposure. The overlying part of Unit IV (Cores 122-761C-12R to $-14 \mathrm{R}$ ) consists again of foraminiferal packstones and wackestones (MFT 3 and MFT 8). It also includes grainstones (foraminifers, MFT 15), coated-grain (MFT 16), and oolitic grainstones (MFT 17, Pl. 1, Fig. 5). This sequence documents the repeated shifting between the intertidal and shallow lagoonal depositional environment. Biogenic allochems are the same as above. Depending on the microfacies type, there is a predominance of foraminifers, ooids, or peloids.

\section{Site 764}

Unit VII (278.15-290.0 mbsf). An open-marine shelf environment is represented in Core 122-764B-31R (Figs. 7 and 9). The alternation of highly bioturbated marls, dark clayey carbonate mudstones, and mudstones to wackestones signifies deposits of an environment below wave base. The limestones (echinodermal wackestones to packstones, MFT 11; skeletal wackestones, MFT 6; and wackestones, MFT 2) contain pelecypod or echinoderm fragments and some quartz and feldspar debris. Other possible biogenic components were destroyed by strong dolomitization.

Unit VI (73.5-278.15 mbsf). The amount of allochems increases from Unit VII to Unit VI. The uppermost samples of Unit 


\section{SITE 761}

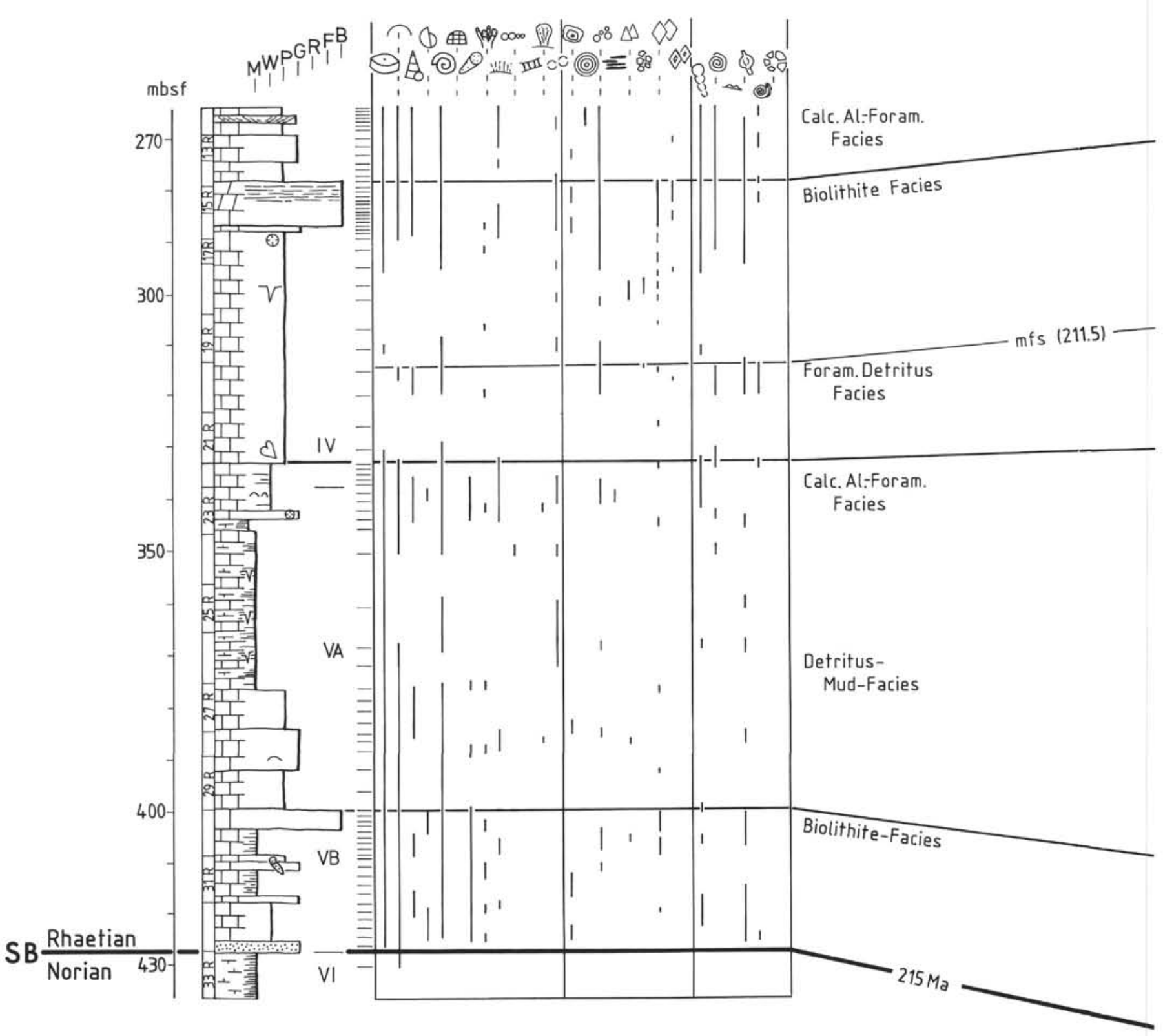

Figure 7. Parallelization of Sites 761 and 764 according to the microfacies and sequential evolution. The biogenic and abiogenic allochems and some diagenetic features are plotted against the lithological column. Further explanations, see text. See Figure 4 for legend. M-B correspond to mudstones to boundstones, SB = sequence boundary, MFS = maximum flooding surface, and mbsf $=$ meters below seafloor. 


\section{SITE 764}

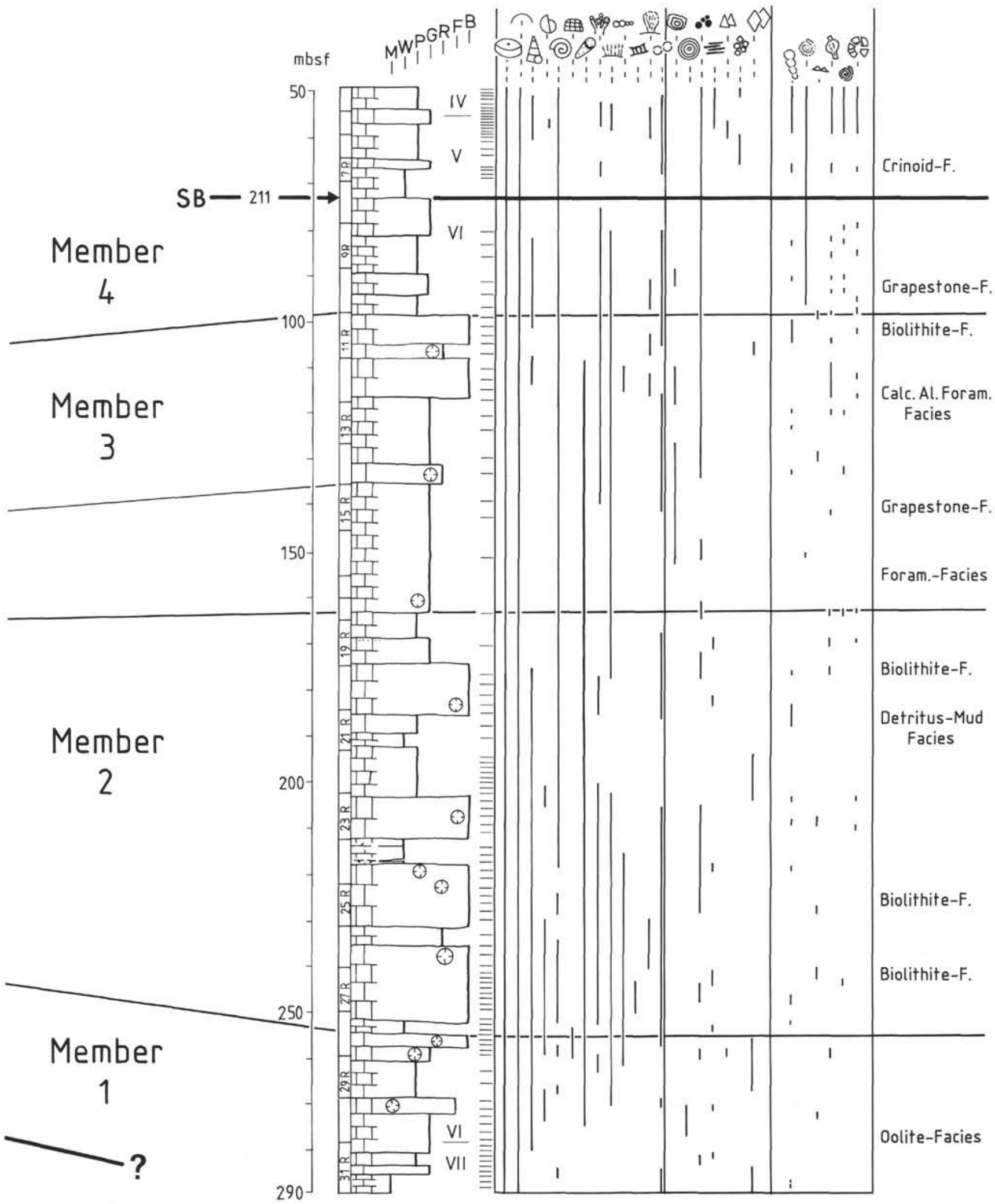

Figure 7 (continued). 


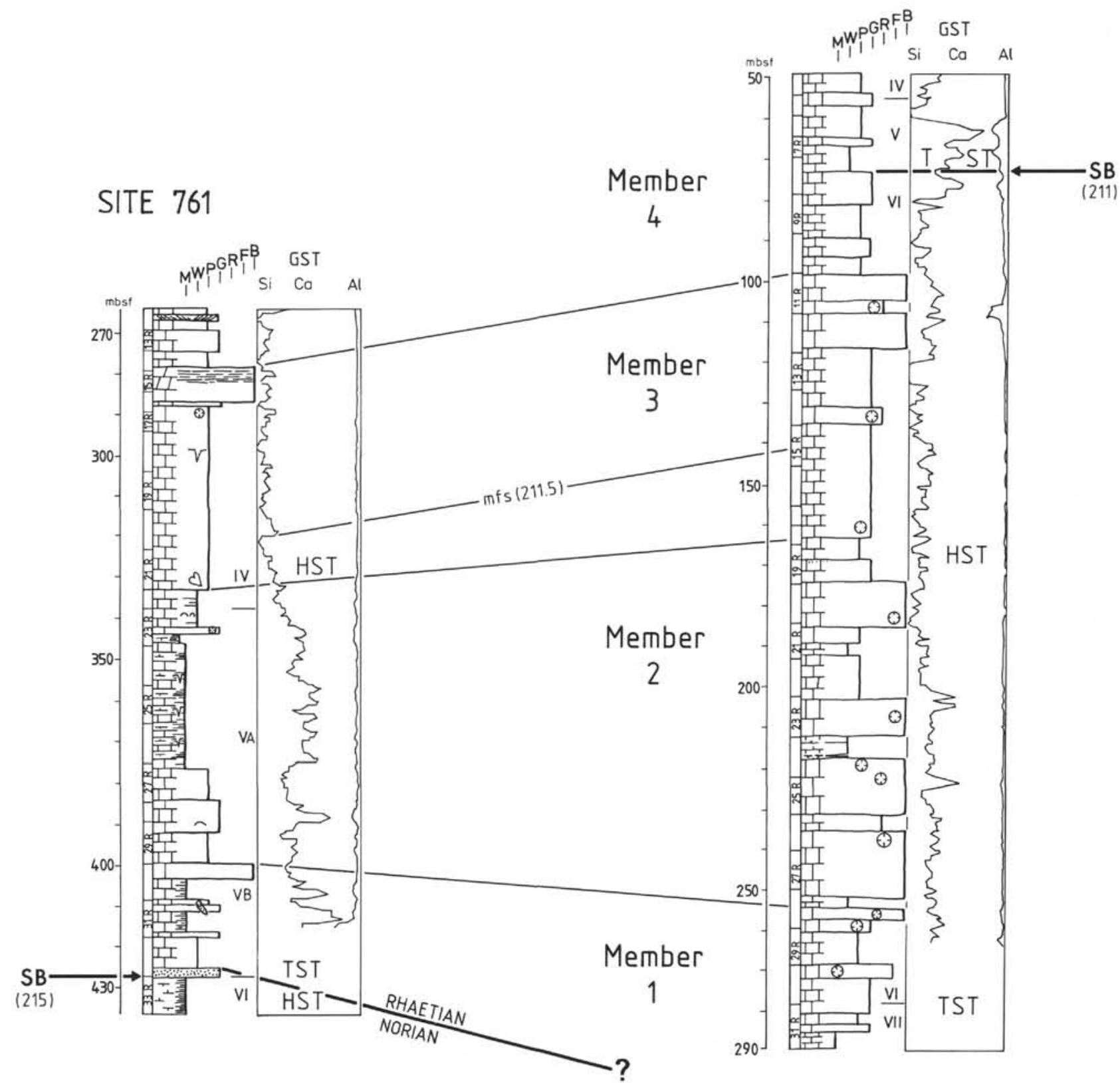

Figure 8. Wireline $\log$ (GST = gamma-ray spectroscopy tool, normalized Si-, Ca-, and Al-contents) of Sites 761 and 764 in comparison with lithology, sequence analysis, and sea-level changes. Note the two Si peaks in the lower part of both sites which agree with the parallelization of profiles according to the microfacies of limestones. For further explanation, see text. See Figure 4 for legend. The numerals IV, V, VI, and VII correspond to lithological units as described in text. HST = highstand systems tract, TST = transgressive systems tract, $\mathrm{SB}=$ sequence boundary, $\mathrm{MFS}=$ maximum flooding surface, and $\mathrm{mbsf}=$ meters below seafloor.

VII consist mainly of packstones to grainstones. This was the prerequisite ("basal pile," cf. Walker and Alberstadt, 1975) for the later reef development, which was controlled by an interplay between substrate, water energy, sea-level fluctuations, and growth potential of the reef organisms (Fagerstrom, 1987).

"Normal" oolites occur only in the lower part of the site (Core 122-764B-30R), where reef development had not yet started to shelter the lagoon from the open sea. However, the coated-grain grainstones (MFT 16) and skeletal packstones to grainstones of the grapestone facies (MFT 10) occur at the bases of each reef cycles ("stabilization stage," cf. Walker and Alberstadt, 1975).

Calcisponges formed the first patch reefs ("colonization stage," cf. Walker and Alberstadt, 1975; Cores 122-764B-29R to -30R; calcisponge floatstone, MFT 14), which generally interfinger with skeletal pack- to floatstones (MFT 10 to 13). The predominance of calcisponges in the lower part (Cores 122764B-29R to $-30 \mathrm{R}$ ) may be caused by relatively calm water conditions in the beginning part of each reef cycle. After that, Thecosmilia- and 


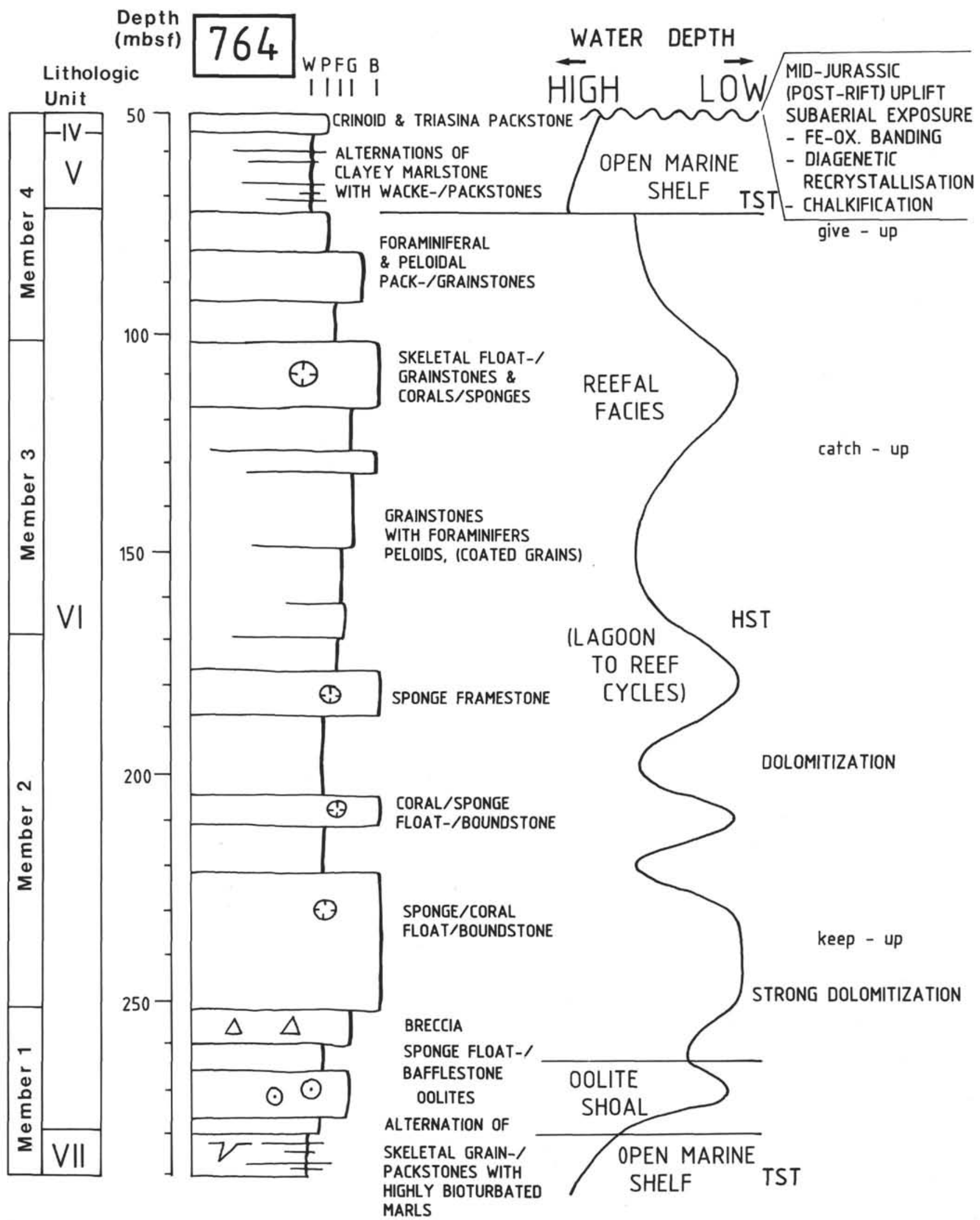

Figure 9. Cyclicity within the Rhaetian of Site 764 indicates a keep-up to catch-up carbonate system (cf. Kendall and Schlager 1981). This development characterizes a transgressive to highstand systems tract transition (cf. Sarg, 1988). Note the post-rift unconformity capping the top of the Rhaetian. Ranges of sea-level changes are in the order of $\mathrm{m}$-scale. HST $=$ highstand systems tract, TST = transgressive systems tract, $\mathrm{SB}=$ sequence boundary, and $\mathrm{M}-\mathrm{B}$ correspond to mudstones to boundstones. 


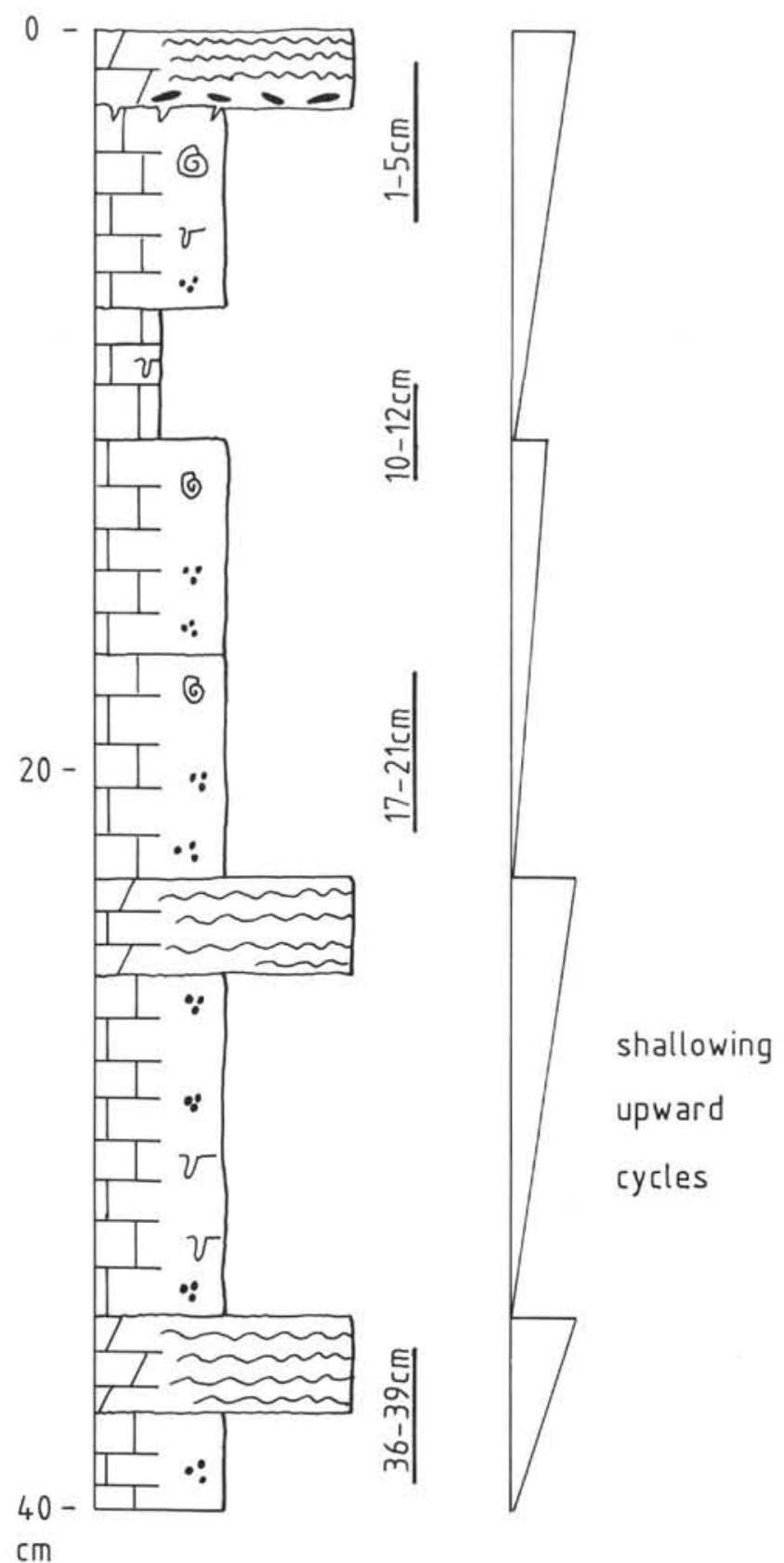

Figure 10. Regressive shallowing-upward cycles within the upper part of Site 761. Bioturbated wackestones (shallow subtidal) grade upward via foraminiferal packstones to grainstones into inter- to supratidal algal bindstones. Subaerial exposure is indicated by sheet cracks, mud cracks, and keystone vugs in the upper part. The cycles are similar to the small-scale regressive cycles described from the Northern Calcareous Alps (bedded Dachstein-limestone, cf. Brandner, 1984).

Astraeomorpha-type corals and hydrozoans occur (Pl. 2, Figs. 4 and 5, "diversification" and "domination stages," cf. Walker and Alberstadt, 1975).

Such reef cycles were found four times in Cores 122-764B$24 \mathrm{R}$ to $122-764 \mathrm{~B}-11 \mathrm{R}$ (Fig. 9). The most typical section is from Core $122-764 B-30 R$ to Core $122-764 B-25 R$ in the lower part of the site. Back-reef (lagoonal) and fore-reef sediments are intercalated between the reefal facies. Due to the influence of wave action, they consist of wackestones to rudstones (echinodermal wackestones and packstones, MFT 6 and 11; skeletal wackestones, MFT 7; skeletal packstones to grainstone/grapestone facies, MFT 10; skeletal rudstones, MFT 22).

Based on these alternations, we determined several lagoon to reefal cycles that indicate a "keep-up" to "catch-up" carbonate system (Fig. 9; Scaturo et al., 1989). This interpretation is also supported by the slim shapes of the reef structures recognizable in the seismic reflection lines across Wombat Plateau (Williamson et al., 1989). It may indicate the fast growth of the reef-related organisms, which tried to balance the rising sea level ("keep-up system," Kendall and Schlager, 1981).

Unit V (55.9-73.5 mbsf). The cycles of Unit VI, which can be interpreted as a "transgressive systems tract" (Van Wagoner et al., 1988 ), end abruptly with the second sequence boundary within the Rhaetian. This sequence boundary reflects the global upper Rhaetian transgressive impulse (cf. Vail et al., 1977; Haq et al., 1987), which leads to the Jurassic transgression. At this time the reefal facies was being drowned. The alternations of marls and limestones represent a transgressive systems tract (cf. Van Wagoner et al., 1988).

On the basis of composition, we can distinguish Unit V deposited in a comparatively greater water depth (alternation of limestones with marl and claystones) from Unit IV that represents relatively shallow water depths (no marls, lighter colors, and pure limestones).

The limestones of Unit V consist on the one hand of skeletal packstones with crinoid and brachiopod fragments (MFT 11) and sponge spicules (MFT 7), and on the other hand of peloidal, bioturbated wackestones (MFT 2) with foraminifers (including Triasina hantkeni Mazjon, MFT 3 and MFT 8).

Unit IV (50.0-55.9 mbsf). The uppermost Rhaetian sequence contains crinoidal packstones and grainstones with foraminifers. Triasina hantkeni Mazjon is very abundant. Due to high alteration or recrystallization it is difficult to find the primary fabric and microfacies types in Sections 122-764B-4R-1/122-764A-7R-1 (PI. 2, Fig. 6) (see "Limestone Diagenetic History" section, this chapter).

The top of Unit IV is capped by a major disconformity, the post-rift unconformity (Fig. 9).

\section{Dredge Samples}

The dredge samples from the northern Wombat Plateau escarpment and the Cygnet Canyon and Echidna Spur (Fig. 1) contain Upper Triassic and possibly Jurassic shallow-water carbonates and an upper Lower to Middle Jurassic (W. Brenner, pers. comm., 1989) coal-measure sequence (silty claystones, quartz siltstones, and fine sandstones with coal seams). A ferruginous association was interpreted to be the subaerially weathered equivalent of the coal measure sequence or "oxidized flood-plain facies" (von Stackelberg et al., 1980; von Rad and Exon, 1983; von Rad et al., 1990). Data by Quilty (1990) suggest that the youngest shallowwater limestones are of Callovian to Oxfordian(?) age. These samples were re-examined by Kristan-Tollmann and Gramann (this volume). These authors determined a Norian to Rhaetian (perhaps Rhaetian-Liassic) age for the dredged shallow-water carbonates.

The microfacies analysis of the dredged material suggests that, in addition to the Rhaetian microfacies types found at Sites 761 and 764, some new types are present. A modification of MFT 11, which is echinodermal packstone, was found in several samples (northern Wombat escarpment, $S O-8-61 \mathrm{KD} / 3$, and Cygnet Canyon, $R S-56-\mathrm{DR} 04 \mathrm{I}$ and $-\mathrm{K}$ ). This microfacies type (D11) consists exclusively of very densely packed crinoid/echinoderm fragments with large syntaxial rim cements (Pl. 1, Fig. 2) and was not found in Leg 122 carbonates. Therefore, we speculate that a depositional 
setting was that of a comparatively deeper-water swell (cf. Roux et al. 1988, Schott in von Rad et al., 1990) for this crinoid-rich limestone. This may indicate the differentiation of the sedimentation area separated from high horsts, such as the Wombat Plateau proper, from a stable platform into several swells and basins during the Jurassic.

The second microfacies type that was not found in the samples of Leg 122 drill sites is a mudstone to wackestone without calcareous fossils, but with large wood fragments and some quartz grains ( $R S-56-\mathrm{DR} 02 \mathrm{H}, \mathrm{Swan}$ Canyon). This rock type may represent a transition facies between the Lower Jurassic coal-measure sequence and the postulated comparatively deeper-water Liassic carbonate platform. The carbonates could also be deposited in restricted areas of the coal swamps, caused by hypersaline conditions.

\section{Facies Units and Comparison with Western Tethyan Triassic Outcrops Facies}

The two global Late Triassic sea-level-rise events known from other areas in the world were observed in sediments from Leg 122 sites (Figs. 8 and 11). Detailed comparisons of the geodynamic settings between Europe and the Australian margin were made by Dumont (this volume). He identifies differences between the European and Australian Rhaetian series. The latter shows a sequence boundary inside the upper Rhaetian, in the former the sea-level rise agrees with the Triassic/Jurassic boundary. We agree with his assumption that the difference may be artificial, because the lowermost Hettangian is difficult to date. The renewed upper Rhaetian marine series in the epicontinental area of the "Germanic basin" (Paris basin, cf. Muller et al., 1974; Lower Saxony, cf. Stindler, 1989) confirm a pre-Liassic transgression ("pre-planorbis beds").

However, we cannot exclude the presence of lowermost Liassic in the uppermost cores of Site 764 below the post-rift unconformity.

In addition to these tectono-eustatic sea-level changes, which were probably caused by major plate reorganizations at this time, the Rhaetian facies of the Wombat Plateau shows a conspicuous similarity to that of the western Tethys (cf. Stanley, 1988), e.g., in the Northern Calcareous Alps. Like many fossil reefs, the Wombat Plateau reefs are not directly comparable to recent coral reefs, because extensive wave-resistant frameworks are missing. The marl/limestone alternations within Site 764 can be compared

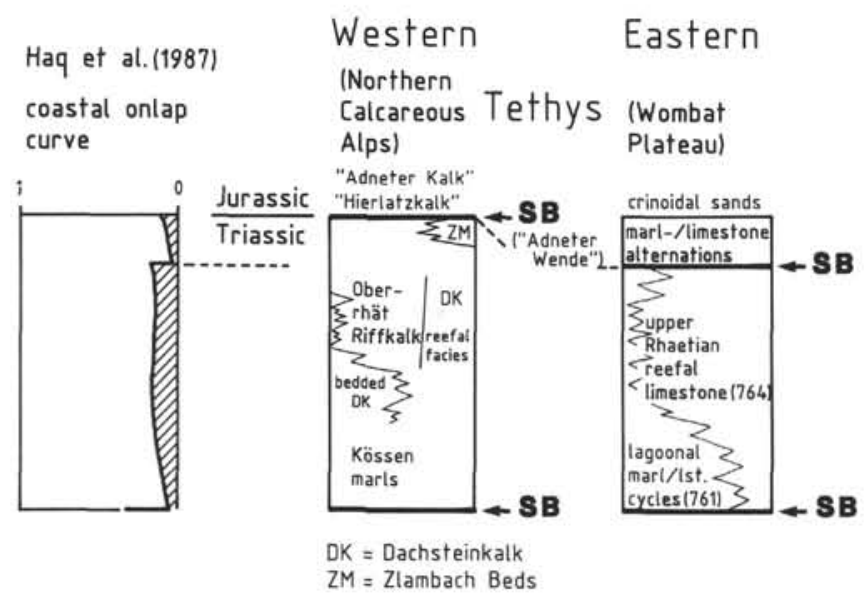

Figure 11. Comparison of western and eastern Tethyan sea-level histories. See text for explanation. Western Tethys modified after Zankl (1971). to the "Kössen facies" (limestone and marly shale facies). Also the northern alpine "Upper Rhaetian limestones" (Oberrhätkalk) could be compared to the reefal series at Site 764 of the same thickness, the "Zlambach beds" to the overlying foraminiferal and crinoidal limestones. It is possible that the early Liassic limestones and marls ("Adnet limestone," "Hierlatz limestone," "Flecken limestones and -marls") correlate with the fine-clastic upper Rhaetian (-Liassic?) series, which overlie the reefal facies in the uppermost cores of Site 764 and are represented in the dredge material from the northern Wombat Plateau escarpment.

Even at a lower level we found an intimate relationship. Comparable to the Rhaetian of the Calcareous Alps (e.g., Piller, 1976; Schäfer, 1979; Schott, 1983; Senowbari-Daryan, 1980; Stanton and Flügel, 1989), several microfacies types of the Rhaetian at Sites 761 and 764 can be combined to characteristic facies units (Fig. 7). Biolithite facies, oncoid/grapestone facies, calcareous algae/foraminifers facies, and detritus mud facies follow each other from reef to back-reef to a restricted lagoon (Fig. 7). For example, the lowermost meters of Sites 761 and 764 show the highest diversity of reef-related organisms and therefore a distinct reef development (Figs. 7 and 9). In the upper part of the sites we found a dominance of the mud/foraminifers facies. The dominance coincides with an increase of foraminiferal genera and species, especially of Triasina hantkeni Mazjon and peloids.

The biolithite facies of the central reef areas consists of several microfacies types. Like many fossil and recent reefal series, it shows a characteristic association of some microfacies types. In the Leg 122 ostracode-rich (MFT 5), echinoderm-rich (MFT 6), and foraminifer-rich limestones (MFT 3, MFT 8, and MFT 15) are intercalated between the individual reef structures. Latter are of boundstones with Thecosmilia- and Astraeomorpha-type corals, calcisponges, and hydrozoans (MFT 24 and MFT 25). Partly algal lamination (MFT 23) occur. Peloidal pack- to grainstones (MFT 9 and MFT 21) are typical fillings of reef-growth cavities (Pl. 2, Fig. 4).

The grapestone/oncoid facies of the uppermost, mostly leeward reef slope is made up of skeletal grainstones to packstones (MFT 10) and coated-grain grainstones (MFT 16).

The algal-foraminiferal-detritus facies of the lower reef slope in transition to the lagoon shows a wide variety of microfacies types (MFT 15 to MFT 7) with a lagoon-ward decrease of reef debris (coral and sponge fragments, larger mollusc shells). In addition to peloids and foraminifers the mud-dominated foraminiferal-mud facies contains fewer biogenic allochems. Bioturbation and rare quartz-grain debris increase. In Figure 7 distinct groups of foraminifers (Nodosariidae, Triasina, Aulotortus, Glomospirella, and Duostominidae and encrusting foraminifers) are plotted against the other biogenic and abiogenic allochems and the lithological column. Following Schäfer and SenowbariDaryan's (1981) classification, which subdivides the facies zones according to different associations of foraminifer groups, Triasina was never found in the biolithite and detritus-mud facies ("Kössen" facies), and Opthalmidium was never found in the grapestone-reefal debris and algal-foraminiferal facies of Leg 122 carbonates. The upward increase in the amount and diversity of foraminifers at Site 764 reflects the replacement of the biolithite facies by the grapestone/reefal-debris facies, and then by the algal-foraminiferal facies.

The description of microfacies and the facies evolution at our drill sites show that the reefal facies of Site 764 is similar to the "Oberrhätriffkalk" (Upper Rhaetian reefal limestone; Fabricius, 1974; Stanton and Flügel, 1989) or "Dachsteinriffkalk" (Dachstein reef limestone) (Zankl, 1971) of the Northern Calcareous Alps. Site 761 reflects the lagoonal facies of the "gebankter Dachsteinkalk" (bedded Dachstein limestone) (Piller, 1976) with regressive cycles similar to those described by Brandner (1984). 


\section{Correlation of Sites 761 and 764}

Because of the lack of age-distinctive faunas and floras (the sediments consist mainly of facies-related fossils), there was no simple method to correlate the Rhaetian series between Sites 761 and 764 . The $20-\mathrm{km}$ distance between the two drill sites and the strong facies changes make detailed comparisons difficult. But similar sedimentology, microfacies, and diagenetic features show a comparable evolution within the two drill sites (see above, Fig. 7). This fact was probably related to changes in the relative sea level that affect the whole Wombat Plateau in the same way. Local factors modifying the facies were therefore influenced by supraregional or global events.

Our attempt to correlate the two Rhaetian sites is illustrated in Figure 7. After a typically rapid transgression, represented at Site 761 , we see the development of a carbonate buildup (Site 761) or reef growth (Site 764) in the lower part (member 1) of both drill sites.

The middle part (member 2) is dominated by limestone/marl alternations with a limestone-dominated section at the base in Site 761. Member 2 of Site 764 also contains some marly (partly dolomitic) horizons in the center and thick limestone units at the base (Fig. 7).

Member 3 is made up of foraminifer- and peloid-rich microfacies types (foraminiferal-algal facies and foraminiferal-mud facies, including Triasina and Megalodon limestones) at both drill sites with a shallowing-upward tendency (Site 761: reversed "Lofer" cyclothems, Fischer, 1964; Fig. 10; Site 764: keep-up cycle, Fig. 9).

Member 4 shows a mud-dominated series containing brachiopods, crinoids, and sponge spicules at Site 764. According to this comparison it is probable that Site 764 is stratigraphically more complete and that the top of Site 761 was eroded to a deeper level than Site 764. The interpretation of a natural gamma-ray log in the unrecovered part of Site 761 (Core 122-761C-11R) by von Rad and Thurow (this volume) shows a 2.5-m-thick uppermost(?) Rhaetian claystone horizon, overlain by a limestone(?) horizon. These beds might be the equivalents of Units V (claystone) and IV (limestone) of Site 764 (Fig. 9).

\section{The Facies Model}

The carbonate intercalations in the fluviodeltaic to marginalmarine Carnian and Norian series occur between thin and evenly laminated siltstones and some are interpreted as allochthonous storm deposits (tempestites) reworked from nearby shallow-water carbonates. Also present are autochthonous or parautochthonous carbonate sands, deposited in restricted areas within interdistributary bays as migrating sand waves. Alternatively, these carbonate sands might have formed on the top of barrier island arcs in front of an abandoned delta lobe with the development of spits, tidal inlets, and subaerially exposed sand bars. Similar facies relationships are observed in modern carbonate environments of the Bahamas (Scholle et al., 1983).

The evolution of the (southern) Wombat Plateau area during the Carnian and Norian began with a Carnian prodeltaic environment that evolved to an intradeltaic lagoon and in a fluviodeltaic/tidal flat environment. The lower Norian rifting event discussed previously was followed by distinct regression during the later Norian with the development of coal swamps in the uppermost part.

During the Carnian and Norian there were several changes from transgressive to highstand systems tracts (Fig. 6). The uppermost, extremely regressive member is a typical latest high- stand systems tract (von Rad et al., this volume; Van Wagoner et al., 1988; Sarg, 1988).

The evolution of Sites 761 and 764 during the Rhaetian started by lower (?) Rhaetian open-marine shelf marl/limestone alternations drilled at Site 761. These alternations were caused by changes of terrigenous supply and energy (storm/fair weather) conditions. Detailed investigations of the origin of limestone/marl cycles await further studies.

In the area of Site 764 the first reef development followed an oolitic shoal phase (see "Stratigraphic Evolution" section, this chapter). Within the lagoonal area, with restricted conditions created by the reef development, Site 761 shows the development of calcisponge patch reefs and corallinacean buildups (member 1 , Fig. 7).

During the "middle" Rhaetian (member 2, Fig. 7) the reefal facies continued in the area of Site 764 . The Site 761 area was dominated by marl/limestone alternations, explained by changing terrigenous input, e.g., periodic high-energy (e.g., storm) events. Biogenic allochems and bioturbation indicate a more restricted environment (intrashelf lagoon), as compared with the marl/limestone cycles of the "lower" Rhaetian of Site 761.

The "upper" Rhaetian (member 3, Fig. 7) was on one hand, characterized by the dominance of grapestone or foraminiferalalgal facies at Site 764 ; on the other hand, Site 761 developed regressive cycles (Fig. 10) from lagoonal foraminifer- and Megalodon-bearing wackestones (shallow subtidal) to algal bindstones (inter- to supratidal).

The "uppermost" Rhaetian (member 4, Fig. 7) transgressive pulse causes renewed sedimentation of marl/limestone alternations at Site 764 that includes crinoids, brachiopod shells, and some sponge spicules.

The relatively deeper-water crinoidal sands, which we found only in dredge samples, may be of Jurassic age (see "Stratigraphic Evolution" section, this chapter).

In summary, we propose continuing tectonic subsidence during the entire Rhaetian from base to top, which resulted in a slow relative sea-level rise. The reefal facies shows first keep-up deposits grading into catch-up cyclic deposits (cf. Scaturo et al., 1989; Kendall and Schlager, 1981) (Fig. 9).

Regression followed by renewed transgression (drowning of the carbonate platform, "sequence boundary") killed the reefal facies ("give-up") and ended the carbonate platform history during the latest Rhaetian.

According to sequence-stratigraphic classifications (Sarg, 1988) the Rhaetian sequence of the Wombat Plateau can be described as the evolution from a transgressive systems tract (lower Rhaetian) via a highstand systems tract (lagoonal and reefal facies of the upper Rhaetian) back to a transgressive systems tract (uppermost Rhaetian) (von Rad et al., this volume).

Figure 12 summarizes our interpretation of the different sedimentation areas of the Upper Triassic (Carnian, Norian, and Rhaetian). They are plotted in a three-dimensional facies model of the Wombat Plateau. The fluviodeltaic setting, the siliciclasticdominated marine environments and the carbonate platform are shown as separate blocks within this block diagram.

Sites 759 and 760 represent the fluviodeltaic-dominated series of the Carnian and Norian. Sites 761 and 764 represent the Rhaetian carbonate platform. The time-equivalent Rhaetian series in the areas of Sites 759 and 760 that have been eroded by the Jurassic post-rift unconformity are assumed to be fluviodeltaic or mixed fluviodeltaic/shallow-water carbonate. Alternatively, there was no deposition at this location during the Jurassic, due to the northward tilting of the Wombat block and emersion of its southern flank. Site 761 reflects the intertidal to shallow-subtidal la- 


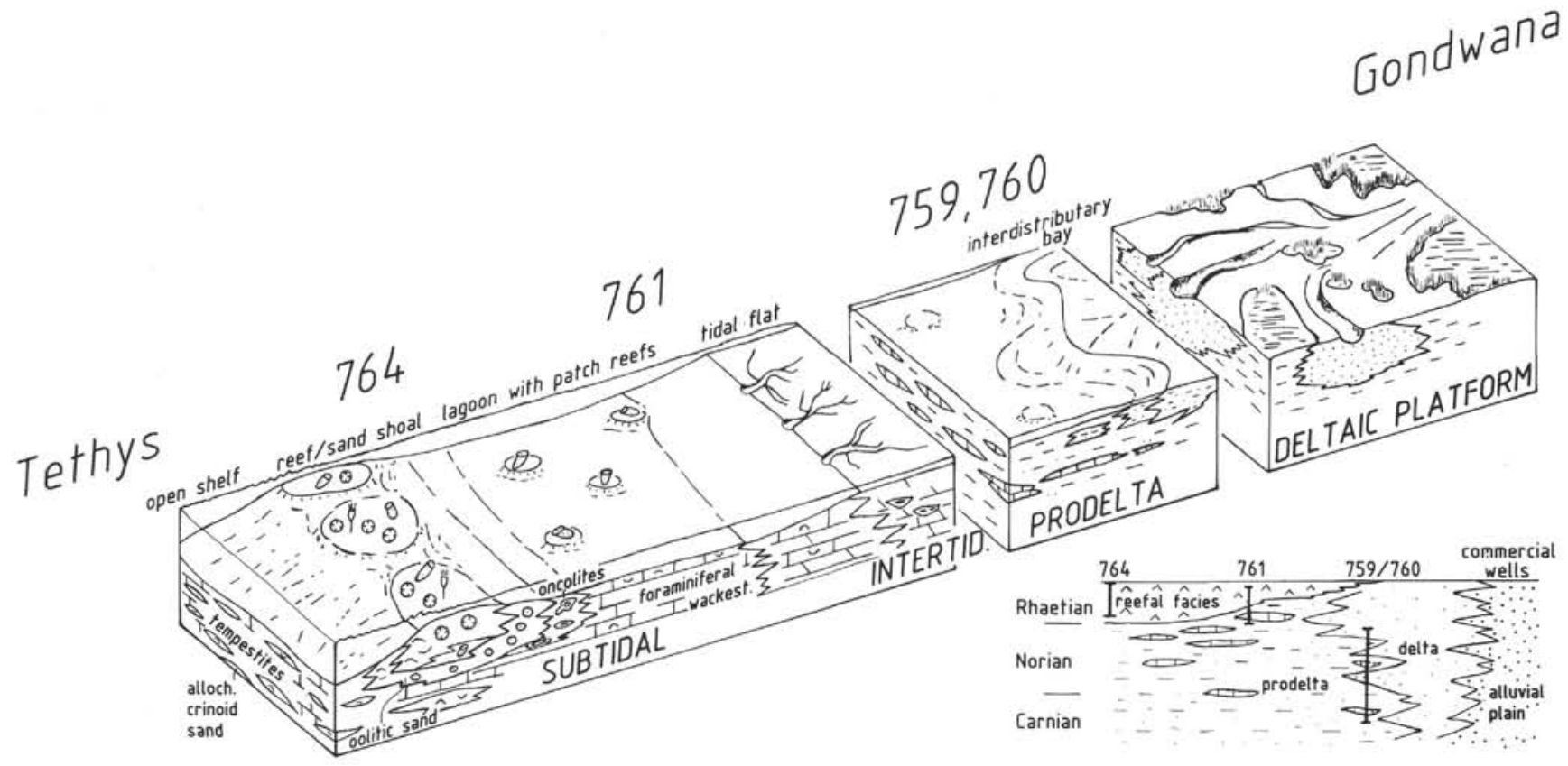

Figure 12. Late Triassic (Rhaetian) generalized facies model of northeast Gondwanan margin (Wombat Plateau). For further explanations, see text.

goonal areas. Site 764 reflects the better ventilated subtidal oolite shoals, reef, and reefal debris areas.

Because all stratigraphic and facies units are summarized in one model, Figure 12 might give the impression that the Rhaetian reefs are interpreted as platform edge buildups. However, based on the lack of genuine reefal framework and the interpretation of the seismic data (Williamson, this volume), we think that the Rhaetian reefal and lagoonal sediments were deposited on a slightly inclined carbonate ramp with randomly distributed patch reefs and without a marginal "barrier" reef (Röhl et al., 1991).

\section{LIMESTONE DIAGENETIC HISTORY}

The carbonates were affected by strong diagenetic alteration. Especially in the lagoonal to reefal Rhaetian limestones, late-diagenetic alteration destroyed many primary sedimentary and earlier diagenetic features. Therefore, it was not easy to identify diagenetic successions. However, the study of a great number of thin sections ranging from strongly altered biogenic allochems and disturbed sedimentary structures to more-or-less-preserved structures, as well as the cathodoluminescence analysis, allowed the reconstruction of facies as shown in the previous chapters. The diagenetic history is best documented in the varying types of cement. Solution, neomorphism, dolomite, dedolomite, internal sediments, and silica authigenesis occur locally.

\section{Cementation}

Several cement types can be distinguished that were formed in marine-phreatic, meteoric-phreatic, meteoric-vadose, and burialdiagenetic environments.

Limestone types with high primary intergranular porosity are obviously favored for early-diagenetic cementation. They include several cement generations, some of which may sometimes be missing from a given pore.

Marine phreatic cements form isopachous crusts-they may vary in crystal size as well as in the fabric of relics.

Even-rim acicular cement is interpreted as having been of a primary aragonitic mineralogy. It occurs as single layers around the allochems (Pl. 3, Fig. 1) found in voids between septae of originally aragonitic skeletons (corals). This documents the important influence of the substrate on cement mineralogy.

Even-rim fibrous cement occurs around volcanic rock fragments in one sample and was also interpreted as primary aragonite cement (Pl. 3, Fig. 6).

Even-rim cements with bladed crystal (PI. 3, Fig. 3) show the same crystal morphology as cements in analogous sediments (Schroeder, 1979) that consist of high Mg-calcite. Therefore this mineralogy is also assumed for similar cements of the Rhaetian of the Wombat Plateau. Their crystal size and the thickness of the rim differ from sample to sample and sometimes even within the same section. They were formed in the marine-phreatic environment (Moore, 1989). Sometimes they were recrystallized to equigranular cements (Pl. 3, Fig. 2) that may reflect a later overprinting under meteoric phreatic conditions (Harris et al., 1979). Strasser and Davaud (1986) described equigranular cements of primary origin.

Marine cements are best preserved in the Carnian and Norian limestones that are intercalated between siltstones and claystones. Because they were obviously better sealed from circulating pore fluids, they exhibit less porosity and permeability and therefore were protected from strong diagenetic alteration, as observed in the Rhaetian limestones.

Phenomena of the freshwater vadose phase are relatively rare; meniscus cement, micrite bridges (Pl. 4, Fig. 6), gravitational/microstalactitic cement (at the roofs of enlarged vugs, Pl. 4, Fig. 5), and vadose silt (Pl. 4, Fig. 7) were rarely found in secondary pores. Iron $(\mathrm{Fe})$ and manganese $(\mathrm{Mn})$ are generally not found in vadose cements because the vadose zone is usually an oxidizing environment and the oxidized state of $\mathrm{Fe}$ and $\mathrm{Mn}$ cannot be incorporated into the calcite lattice. As a result, vadose cements generally display no cathodoluminescence.

Scalenohedral cements, which may be interpreted as freshwater-phreatic cements, are relatively abundant (Pl. 3, Fig. 7). They consist of clear, columnar "dogtooth" crystals that display unit extinction under crossed nicols. They are a younger generation 
than the even-rim cements. Kerans et al. (1986) suggest that scalenohedral cement was precipitated as low- $\mathrm{Mg}$ calcite from oxidized marine waters at some depth below seafloor. According to Pearson and Shinn (1985), Strasser and Davaud (1986), and Moore (1989), scalenohedral calcites are the product of an earlydiagenetic freshwater-phreatic zone. However, Koch et al. (1989) point out that in general the interpretation of the environment of formation is ambiguous. This may be especially valid for older rocks that have undergone many recrystallization processes. Scalenohedral crystals in Leg 122 samples occur both in primary and secondary pores and are interpreted as products of meteoric diagenesis due to the association with other phenomena of subaerial exposure (strong recrystallization effects, moldic porosity, and keystone vugs).

The major type of cement, the granular (blocky) calcite cement, belongs to the burial-diagenetic stage. This cement partly closed the remaining pore space (Pl. 3, Fig. 3). Blocky calcite occurs in all types of grain-supported lithofacies and shows a mosaic of equant crystals with boundaries that are frequently curved, indented, or even serrate with relics of skeletal structure, earlier cements, or sediment fills. Its occurrence in late-diagenetic fractures, which cross-cut other diagenetic features, suggests a very late origin for blocky calcite. It is one of the latest products in the diagenetic sequence.

The syntaxial overgrowth in crinoidal limestones (Pl. 1, Fig. 2 ) is difficult to explain. This phenomenon is interpreted to have been formed under meteoric-phreatic conditions (cf. Walkden and Berry, 1983), marine-phreatic conditions (Longman, 1980), marine burial (Kerans et al., 1986), or during burial diagenesis (Koch et al., 1989). The non-luminescence of syntaxial cements in the Leg 122 in grainstones suggests a meteoric-phreatic origin of these rims.

\section{Noncalcareous Authigenesis}

Silicification of corals (Pl. 3, Fig. 8) and crinoids occurs in the lower part (Cores 122-764B-30R through -28R) and the uppermost part (Cores 122-764B-5R through -6R) of Site 764. After Koch et al. (1989), this is the product of an early-diagenetic process produced only under tens of centimeters to meters of sediment overburden. The silica in Leg 122 samples may be derived from the skeletal opal of sponge spicules, which were generally dissolved and then calcitized during the early-diagenetic shallow-burial stage.

In Cores 122-764A-7R and 122-764B-5R, macroscopic lamination presumably of iron oxide was found (see Shipboard Scientific Party, 1990). The distribution of the elements shows high Fe and $\mathrm{Mn}$ contents in this horizon. By using XRD we could only detect goethite, but no manganese oxides. SEM and energy-dispersive X-ray (EDX) also show the existence of a manganese mineral (rhodochrosite?) in small interstices of goethite (Pl. 5, Figs. 2 and 3). This layer, which is tens of centimeters thick, is situated $0.5 \mathrm{~m}$ to $8 \mathrm{~m}$ (Hole $764 \mathrm{~A}$ ) or $1.2 \mathrm{~m}$ to $10 \mathrm{~m}$ (Hole $764 \mathrm{~B}$ ) below the top of the Rhaetian. Because of the poor core recovery, no detailed information is available from either hole. The individual laminae crossing biogenic allochems (e.g., crinoid fragments, Pl. 5, Fig. 1) indicate the diagenetic origin of this layer. This was supported by the $\mathrm{Fe} / \mathrm{Mn}$ group in the correlation matrix that shows no relationship to the other sedimentation-related elements (see "Cation Mobility" section, this chapter). The laminated horizon was underlain by a limestone sequence, several tens of centimeters to meters thick, very strongly recrystallized, from which the $\mathrm{Fe}$ and $\mathrm{Mn}$ was possibly derived. Apparently, metal-rich interstitial waters migrated up through the sediment column. The overlying sediments do not show this kind of $\mathrm{Fe}$ - and $\mathrm{Mn}$-impregnation.
However, they exhibit some iron-oxide impregnations of fossils (mainly foraminifers) and the first indicators of "chalkification," which Domingo (1989) interprets as evidence of meteoric phreatic diagenesis. According to James (1974), the chalkification results from preferential solution along linear intercrystalline contacts.

According to Roy (1981), diagenetic remobilization of $\mathrm{Fe}$ and $\mathrm{Mn}$ is widespread. $\mathrm{Mn}^{4+}$ and $\mathrm{Fe}^{3+}$ are reduced to $\mathrm{Mn}^{2+}$ and $\mathrm{Fe}^{2+}$ by the decomposing organic matter through the consumption of oxygen. $\mathrm{Mn}^{4+}$ and $\mathrm{Fe}^{2+}$ are easily dissolved in reduced interstitial water and tend to be transported upward by pore solutions. Their redeposition takes place at the reduction/oxidation boundary, usually near the sediment/water interface. In our samples, the position of this horizon several tens of centimeters to probably several meters below the top of the Rhaetian section has to be explained. What kind of a reduction/oxidation boundary was it? In our model this horizon reflects the boundary between sediment with water-filled pores and sediment with air-filled pores. This is supported by the occurrence of the chalkified sediment above the iron-oxide bands and by the upward-increasing porosity and dedolomitization. But are the diagenetic features caused by subaerial exposure strong enough to support this model?

Another model would be the assumption of a fossil watertable/groundwater level that demands the existence of a freshwater lens within the Wombat Plateau. In both cases, Wombat Plateau must have been uplifted above sea level during (at least part of) the Jurassic. This is also the best explanation for the lack of Jurassic series (see "Conclusions" section, this chapter).

\section{Porosity Development}

Primary permeability was generally low in Leg 122 carbonates. Using the classification of Choquette and Pray (1970), intraparticle (predepositional) and interparticle (depositional) primary porosities were determined. Intraparticle porosity occurs typically in corals, calcisponges, and in the network of echinoderm fragments. Sedimentary reworking was ubiquitous, resulting in very coarse grain size (grainstones and rudstones), which attains a high porosity and permeability.

Vuggy and fenestral porosity occur in inter- to supratidal dolomitic stromatolites (algal bindstone, MFT 23, P1. 1, Fig. 1). Shelter porosity and keystone vugs were observed in rudstones to grainstones.

Most shallow-marine carbonate sequences bear the imprint of meteoric diagenesis (Moore, 1989). Because of the general aggressiveness of meteoric pore fluids to instable carbonate minerals, it is one of the most important diagenetic settings in the formation of carbonate porosity.

All samples show some evidence of dissolution. Porosities, estimated in thin-sections, range from near 0 up to $40 \%$ by volume in individual samples of Leg 122 and can be classified as fabricselective. This resulted in a progressive destruction of fossils. The pore types are dependent on the microfacies and the diagenetic history of the rock and can be related to small-scale sea-level changes that occurred between the formation of reef cycles.

Most porosity is of secondary origin. Secondary porosity that developed during early exposure was reduced by marine cement or internal sediment. Most molds generated later contain no cements (Pl. 4, Fig. 9). In addition to early periods of dissolution overprinted by marine diagenesis, a later period of dissolution occurred. During initial burial, meteoric waters increased the porosity that might later be partly filled with cements. Enos (1986) interpreted all dissolution in limestones as the result of near-surface meteoric diagenesis. He suggested that initially established meteoric lenses in small back-reef islands extend toward the reef and lagoon during lower sea-level stands. That means 
freshwater penetration into reefs necessitates a slight drop in relative sea level. The early dissolution phenomena of the Wombat Plateau agree well with Enos' (1986) observations and assumptions.

Intercrystal porosity develops during late dolomitization ( $\mathrm{Pl}$. 4, Fig. 1). Sometimes dolomite crystals have dissolved cores because of the variations in chemical composition of different zones (dedolomitization, Pl. 4, Fig. 1; see "Dolomites and Dolomitization" section, this chapter). Moldic (oomoldic and biomoldic) porosities are very common in both grain- and mudsupported lithologies and were formed by the selective removal (solution) of the former allochems composed of instable carbonate mineralogy (Pl. 5, Figs. 6 to 11). Individual grains (Pl. 2, Fig. 2 ) and cements commonly show varying degrees of dissolution, which start with the leaching of single crystals (Pl. 5, Figs. 4 and 5). Dissolution surfaces within the cement suggest a meteoric origin. According to the classification of Constantz (1986), the dissolution is mainly diffusion-controlled in Leg 122 carbonates. Then the dissolution is almost uniform on all surfaces (Pl. 5, Fig. 4) by which the crystals become rounded. We also found selective surface-reaction controlled dissolution. Etch pits formed around crystal defects (Pl. 5, Fig. 5).

The highest average porosity values are observed in foraminiferal, oolitic, and coated-grain grainstones. Their dissolution depends in part on the degree of protective cementation that shows the circulation of the aggressive fluids, especially on a microscopic scale. The dissolution was obviously mineralogy-selective and released calcium carbonate $\left(\mathrm{CaCO}_{3}\right)$ into the pore water to be re-precipitated as potential calcite cement elsewhere (cf. Harris and Halley, 1979). Mg-calcite components such as coralline algae and foraminifers were preserved for longer periods. Low-Mg-calcite biogenic allochems, such as brachiopods, and ostracodes, and high-Mg-calcitic echinoderms (with relatively high content of organic carbon), were very resistant both to dissolution and dolomitization processes. Porosity depends on microfacies types and therefore on the depositional environment with a later overprint by diagenetic alteration (see "Diagenetic Model" section, this chapter).

Purser and Schroeder (1986) suggest that part of the secondary porosity may be related to dissolution due to the lowering of $\mathrm{pH}$ that follows the decomposition of organic matter. According to Mussmann et al. (1988), dissolution may have been associated with organic maturation. Aggressive pore fluids are common in the deep surface because of higher temperatures, dissolved organic acids, carbon dioxide, hydrogen disulfide, and other components released into pore fluids during mineral phase changes and thermal degradation of organic matter and hydrocarbons (Moore, 1989). According to this author, the resulting pore types are generally solution-enlarged, intergranular pores evolving into vugs. Moldic porosity is rare.

Because the most important porosity type of Wombat Plateau carbonates is moldic, the origin of pores described above can nearly be excluded.

In summary, post-depositional dissolution phenomena are the most common diagenetic features observed in the Rhaetian carbonates. Because post-depositional cements occur in extremely small amounts, it is very difficult to obtain representative samples for isotopic analysis. This makes carbon and oxygen isotope studies (e.g., Sarti and Kälin, this volume) ambiguous.

A probable early-diagenetic, fabric-selective (moldic) dissolution that was associated with other features of a meteoric phreatic to meteoric vadose origin, and the primary facies (algal bindstones, shoal-grainstones, and reef-limestones) could be distinguished from a later diagenetic facies. The second dissolution phase shows fabric-selective leaching, and, opposite to the first phase, no even-rim or scalenohedral cementation occurs in the molds.

\section{Dolomites and Dolomitization}

In the Upper Triassic carbonates of the Wombat Plateau, dolomitization features are abundant and occur in different facies types and at different stratigraphic levels. The degree of dolomitization ranges from scattered dolomite rhombs in a micrite matrix to complete dolomitization (Pl. 4, Figs. 1 to 4 ). In general, dolomitization began within the most porous and permeable facies types (e.g., grainstones and reef-related floatstones to boundstones).

Several types of dolomite occurrences were identified. The complete or nearly complete dolomitization of bindstones is characterized by small anhedral dolomite crystals. Various sedimentary and early-diagenetic features indicate very rapid lithification and early dolomitization (e.g., many desiccation cracks and abundant shrinkage pores within algal mats). Due to its restriction to bindstone lithology (Pl. 1, Fig. 1), this type of dolomitization is believed to be of early-diagenetic origin (supra- or intertidal). Analogous early-diagenetic dolomites are known from Holocene sabkha environments (Shinn, 1983).

The degree of dolomitization in wackestones and packstones ranges from scattered dolomite rhombs via isolated dolomitic patches to the complete dolomitization of the sediment (PI. 4, Figs. 1 and 2). Hypidiomorphic to idiomorphic dolomites (Pl. 4, Fig. 2) were formed in the rocks and replaced sedimentary and early-diagenetic structures. The reduction of $\mathrm{SO}_{4}{ }^{2-}$ to sulfide (the formation of pyrite removed the $\mathrm{SO}_{4}{ }^{2-}$ ions from pore water Baker and Kastner, 1981) favored dolomitization at burial depths of a few meters to tens of meters (Koch et al. , 1989).

Due to the varying degree of dolomitization within individual samples, shallow-burial dolomitization is considered as the most probable diagenetic environment of dolomitization.

The euhedral dolomite rhombs display a distinct zonation in cathodoluminescence (CL) and sometimes also under transmitted light (Pl. 4, Fig. 1). The distinct zonal boundaries give evidence for the lack of diffusion of $\mathrm{Fe}, \mathrm{Mn}$, and $\mathrm{Mg}$. The different $\mathrm{CL}$ colors reflect differences in the chemical composition of each zone. $\mathrm{Mn}$ is the activator, and iron and $\mathrm{Mg}$ may quench the luminescence. This reflects variations in chemical composition or the $\mathrm{Eh} / \mathrm{pH}$ conditions of the pore fluids from which the dolomite was precipitated.

The dolomitization of oolitic grainstones started within the nuclei of the individual ooids. There is a transition to completely dolomitized grains.

The dolomitization of geopetal micrite fillings in interparticle pores of grainstones was probably formed by $\mathrm{Mg}$-rich solutions, which were generated by the transformation of high- $\mathrm{Mg}$ calcite to low-Mg calcite. This occurred in the subtidal to shallow burial environment.

Dolomite cement, lining moldic or primary pores is very rare. It is also interpreted as having originated during the high- $\mathrm{Mg}$ calcite to low-Mg calcite transformation (shallow burial or subtidal).

Complete or nearly complete dolomitization of floatstones to packstones is a characteristic feature in some horizons, especially in the lower reef cycle of Site 764 (Core 122-764B-29R and $-28 \mathrm{R})$, but it is also present at Site 761 .

Contrary to the dolomitization features described above, the high-Mg to low-Mg calcite transformation was probably not adequate to produce the large amount of dolomite. Dolomites are always associated with dissolution phenomena (secondary poros- 
ity, in-situ breccia, chalkification, clay-silt-oxide-infiltrate, and solution-enlarged joints) and fractures ("microkarst"). The intimate relationship between dolomitization and meteoric diagenesis suggests a dolomitization mechanism in a mixing zone of meteoric and marine brines. A "mixed water" dolomitization model requires that the platform was emergent during dolomitization. Because carbonate platforms can be maintained near sea level for extended periods, the influence of freshwater flushing of the platforms, with associated massive diagenesis, is significant.

The features indicate that weathering of the Core 122-764B$29 \mathrm{R}$ and $-28 \mathrm{R}$ began during an intra-Rhaetian relative sea-level drop and resulting subaerial exposure. The relatively minor karstification at the Wombat Plateau is probably due to short duration of exposure and low paleoslope or to a relatively dry climate. Intensive karstification resulted in an general increase in porosity and permeability and favored dolomitization (Henrich and Zankl, 1986).

The dolomitization features were also overprinted during late dolomitization that caused the recrystallization to large rhombohedrons (Pl. 4, Fig. 1).

Dedolomitization also occurs. We found dolomite rhombs that show signs of recalcitization (Pl. 4, Fig. 1). Some rhombohedrons exhibit clear outer rims and a dusty cloudy brownish microcrystalline center (Pl. 4, Fig. 1), which may be the result of dedolomitization (cf. Sass and Katz, 1982). More common are recalcitized patches, the characteristic structure of which indicates a former dolomitic composition ("composite calcite rhombohedrons") (Evamy, 1967) (Pl. 4, Fig. 3).

Dedolomitization features were most commonly observed in samples from Site 761 because this site contains facies-related, small-scale dolomitizations (single rhombs or patches) throughout the profile. We found an upward increase of both dedolomitization features and porosity, especially in the uppermost section of the profile (Fig. 10). We relate this to the increasing freshwater influence from above. According to our model this means that the Wombat Plateau was an emerged island after deposition of the Rhaetian (-Liassic?) and before its renewed subsidence during the (Late Jurassic? to) early Neocomian. Freshwater flushing during younger karst periods seems to have caused dedolomitization phenomena in the earlier dolomites.

\section{Cation Mobility}

Over 80 samples were analyzed by XRF for 36 elements in order to (1) determine the chemical composition, especially of the trace elements, (2) demonstrate diagenetic alterations, and (3) characterize single microfacies types. Table 2 shows the extreme values beneath the arithmetical mean and the median of the analyzed elements for all limestone samples.

Strontium ( $\mathrm{Sr}$ ) tends to migrate during carbonate diagenesis. Only the bioturbated and peloidal wackestones, and the Carnian calcareous algal-bearing grainstones, contain higher $\mathrm{Sr}$ values. Samples of Site 764 generally show low $\mathrm{Sr}$ values. They are impoverished in $\mathrm{Sr}$, which could be a consequence of meteoricphreatic diagenesis.

Chromium $(\mathrm{Cr})$ and vanadium $(\mathrm{V})$ are elements of the terrigenous phase. Therefore, wackestones and packstones show higher values (Fig. 13). The V/Cr-ratio (Fig. 13) can be used as an indicator for the redox conditions ( $\mathrm{V} / \mathrm{Cr}>1$, reducing environment; $\mathrm{V} / \mathrm{Cr}<1$, oxidizing environment). Foraminiferal wackestones, packstones, and grainstones, and peloidal packstones and grainstones, show high $\mathrm{V} / \mathrm{Cr}$ ratios. The amount of organic matter played an important role. Oxygen depletion during rapid sedimentation could produce reduced "microenvironments" within the sediment.
Table 2. Oxide (\%) and element (ppm) composition of analyzed Triassic carbonates.

\begin{tabular}{|c|c|c|c|c|}
\hline & Mean & Median & Maximum & Minimum \\
\hline $\mathrm{SiO}_{2}$ & 3.71 & 2.06 & 25.75 & 0.19 \\
\hline $\mathrm{TiO}_{2}$ & 0.06 & 0.04 & 0.23 & 0.00 \\
\hline $\mathrm{Al}_{2} \mathrm{O}_{3}$ & 1.12 & 0.74 & 4.51 & 0.14 \\
\hline $\mathrm{Fe}_{2} \mathrm{O}_{3}$ & 1.58 & 0.64 & 31.03 & 0.00 \\
\hline $\mathrm{MnO}^{3}$ & 0.12 & 0.11 & 1.88 & 0.00 \\
\hline $\mathrm{MgO}$ & 4.06 & 1.68 & 18.43 & 0.2 \\
\hline $\mathrm{CaO}$ & 45.85 & 44.91 & 54.83 & 15.1 \\
\hline $\mathrm{Na}_{2} \mathrm{O}$ & 0.44 & 0.39 & 0.91 & 0.1 \\
\hline $\mathrm{K}_{2} \mathrm{O}$ & 0.23 & 0.13 & 1.35 & 0.02 \\
\hline $\mathrm{P}_{2} \mathrm{O}_{5}$ & 0.07 & 0.05 & 0.47 & 0.02 \\
\hline $\mathrm{SO}_{3}$ & 0.35 & 0.7 & 1.75 & 0.00 \\
\hline As & 19 & 17 & 55 & 1 \\
\hline $\mathrm{Ba}$ & 69 & 55 & 325 & 1 \\
\hline $\mathrm{Bi}$ & 10 & 10 & 10 & 1 \\
\hline $\mathrm{Ce}$ & 25 & 25 & 28 & 1 \\
\hline Co & 0 & 0 & 1 & 1 \\
\hline $\mathrm{Cr}$ & 23 & 22 & 47 & 1 \\
\hline $\mathrm{Cu}$ & 23 & 23 & 41 & 11 \\
\hline $\mathrm{La}$ & 26 & 26 & 37 & 1 \\
\hline Mo & 5 & 4 & 9 & 1 \\
\hline $\mathrm{Nb}$ & 6 & 6 & 18 & 1 \\
\hline $\mathrm{Ni}$ & 9 & 9 & 21 & 1 \\
\hline $\mathrm{Pb}$ & 13 & 11 & 58 & 1 \\
\hline $\mathrm{Rb}$ & 9 & 7 & 28 & 1 \\
\hline $\mathrm{Sc}$ & 4 & 3 & 6 & 1 \\
\hline Sn & 23 & 23 & 33 & 1 \\
\hline $\mathrm{Sr}$ & 408 & 304 & 2142 & 91 \\
\hline $\mathrm{Ta}$ & 0 & 0 & 1 & 1 \\
\hline $\mathrm{Th}$ & 9 & 8 & 15 & 1 \\
\hline U & 7 & 7 & 8 & 1 \\
\hline V & 33 & 31 & 83 & 1 \\
\hline W & 11 & 10 & 11 & 1 \\
\hline$Y$ & 12 & 10 & 48 & 1 \\
\hline $\mathrm{Zn}$ & 19 & 15 & 127 & $i$ \\
\hline $\mathrm{Zr}$ & 22 & 16 & 88 & 1 \\
\hline
\end{tabular}

The analyzed elements are associated with different mineral phases in the sediment, which are shown in the correlation matrix (Fig. 14). The elements $\mathrm{TiO}_{2}, \mathrm{~K}_{2} \mathrm{O}, \mathrm{Al}_{2} \mathrm{O}_{3}, \mathrm{Rb}, \mathrm{Zr}, \mathrm{Na}_{2} \mathrm{O}, \mathrm{Y}, \mathrm{Cr}$, and $\mathrm{V}$ (in decreasing order of correlation to $\mathrm{SiO}_{2}$ ) belong to the terrigenous detritus and are very well correlated with $\mathrm{SiO}_{2}$.

The high correlation between iron and manganese oxides is very important. These elements do not belong to the terrigenous phase but are related to the late-diagenetic cycle (see "Noncalcareous Authigenesis" section, this chapter). Y shows good correlation on one hand to $\mathrm{MnO}$, and on the other hand to $\mathrm{P}_{2} \mathrm{O}_{5}$.

Magnesium oxide is highly negatively correlated with calcium oxide. Therefore, $\mathrm{Mg}$ is absorbed at/by clay minerals and dolomitic samples are of lower importance. Latter maybe recognized by the poor correlation of $\mathrm{Mg}$ to $\mathrm{SiO}_{2}$, and the positive correlation to copper $(\mathrm{Cu})$ and zinc $(\mathrm{Zn}) . \mathrm{Cu}$ and $\mathrm{Zn}$ are to be expected as sulfides in restricted, poorly ventilated, hypersaline environments (primary, early-diagenetic dolomites). The positive correlation of copper with $\mathrm{CaO}$ is remarkable.

\section{The Diagenetic Model}

Based on the petrographic and chemical data presented above, the diagenetic sequence recorded in the samples can be reconstructed (Fig. 15).

Precipitation, dissolution, and recrystallization of carbonate occurred in a complex pattern. The sediments were first subjected to marine cementation. Micritization and even-rim cementation follow each other in all facies types. Micrite infillings of primary pores and pyrite framboids occur sometimes (Fig. 15). Fillings are often micrite and this may be a sedimentary or a diagenetic 

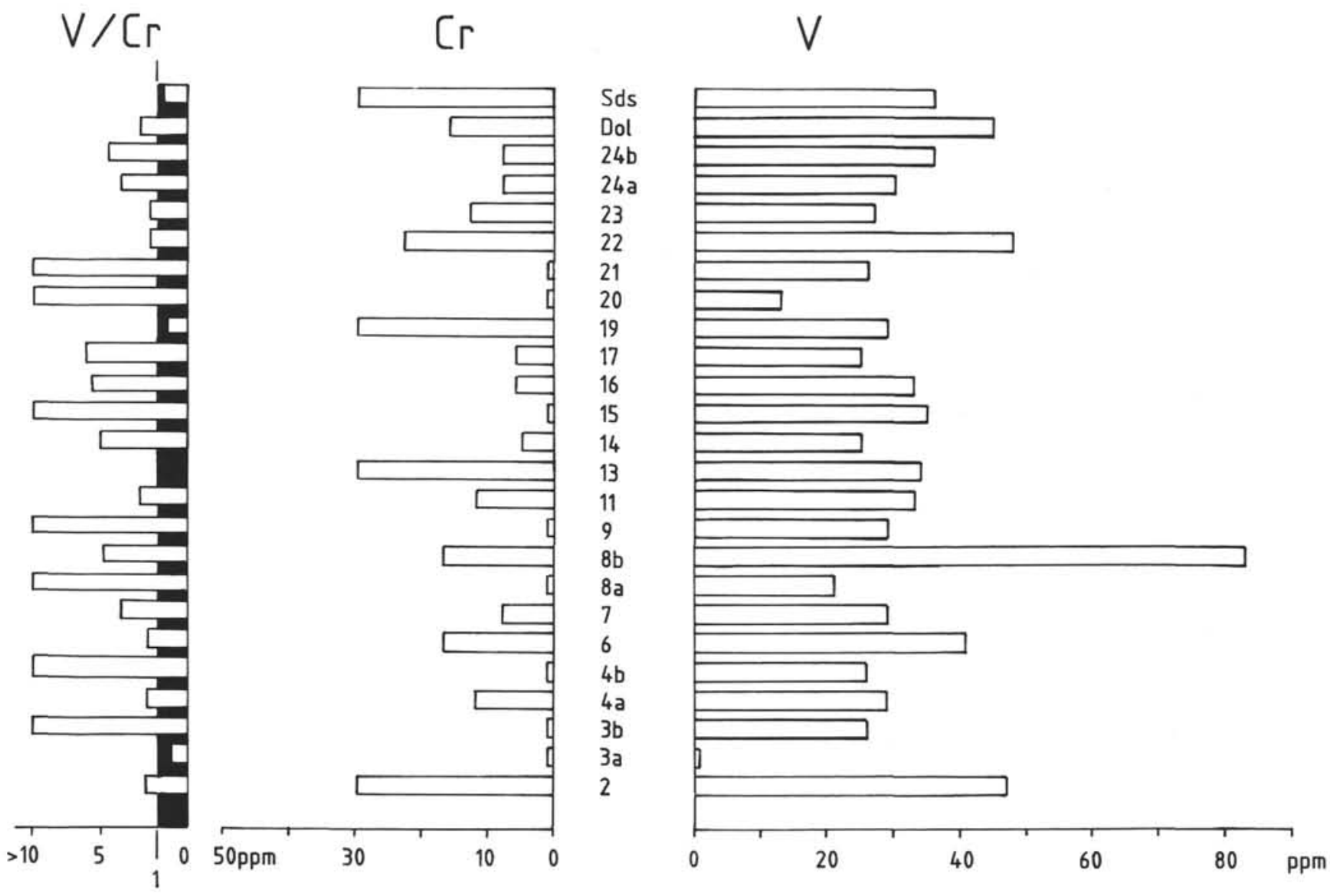

Figure 13. Vanadium, chromium, and V/Cr-ratios compared to the microfacies types of the Wombat Plateau (see Table 1). SDS $=$ sandstone samples, DOL $=$ dolomite samples.

product. Marine cementation may help to stabilize the buildup directly below living coral tissue (Dullo, 1986).

If dissolution is minor, it is generally fabric-selective and preferentially affects frame-builders and foraminifers (Hohenegger and Piller, 1975). The biomolds exhibit marine, even-rim cementation following a meteoric-phreatic, early-dissolution phase (type 1). The mud-supported lithologies show a transition from marine to shallow burial-diagenetic environments.

The grainstone lithologies exhibit the widest range of diagenetic features (Fig. 15) and document the highest variability of the diagenetic environment. This is because of the primary and secondary porosity and permeability, with pathways for diagenetic fluids.

Boundstones and their associated sediments also show different diagenetic phases. The high percentage of primary aragonitic mineralogy of biogenic allochems allowed a high amount of alteration. Also, the position close to sea-level caused several diagenetic alterations; the sediments are easily affected by common small-scale sea-level changes.

The entire sediment profile was affected post-depositionally by meteoric-phreatic (to vadose?) diagenesis during the Jurassic. This caused the formation of Fe- and Mn-laminations (Site 764; see "Noncalcareous Authigenesis" section, this chapter), dedolomitization (Site 761), and chalkification (Site 764), as well as increasing porosity (Site 761).

The Rhaetian sequence was subsequently buried by the overlying deposits. Tentatively, we assume a maximum burial depth of less than $500 \mathrm{~m}$ (Lower Jurassic(?), now eroded plus $250 \mathrm{~m}$ of Cretaceous to Holocene sediments).

\section{CONCLUSIONS}

\section{Geologic History of the Wombat Plateau}

During the Carnian to Norian, the paleoenvironment of the Wombat Plateau was characterized by thick, fluviodeltaic (paralic) deposits. The sediments were shed from large rivers with laterally migrating delta lobes derived from Gondwana, located to the southeast.

The first recovery of Upper Triassic reefal limestones offshore northwest Australia documents a major southward transgression of the southern Tethys Sea that took place during the Rhaetian. It resulted in a major carbonate buildup with local algal bindstones and coral/sponge reefs alternating with lagoonal facies. This facies evolution, the sequence boundaries, and the paleobathymetric trends correlate well with coeval western Tethyan paleoenvironments.

The detailed analysis of diagenetic features (cements, secondary porosities, dolomitization, and recrystallization) and their distribution in the sections of Leg 122 show two major phases of diagenetic alteration.

Syn-Rhaetian cyclic emersion (shoaling upward). Most carbonate diagenesis occurred in the upper Rhaetian because of marine cementation and subaerial exposure. Small relative sealevel variations greatly influence shallow-water areas (e.g., reef builders and calcareous sand shoals) in their development and lifted them from time to time above sea-level. Abundant meteoric phreatic to vadose cements indicate early subaerial exposure within the sequences, especially in bindstones and grainstones. In 
$\mathrm{MgO}$

(०)

$\mathrm{Cu}$

(○)

Sr

(O) (O) (0)
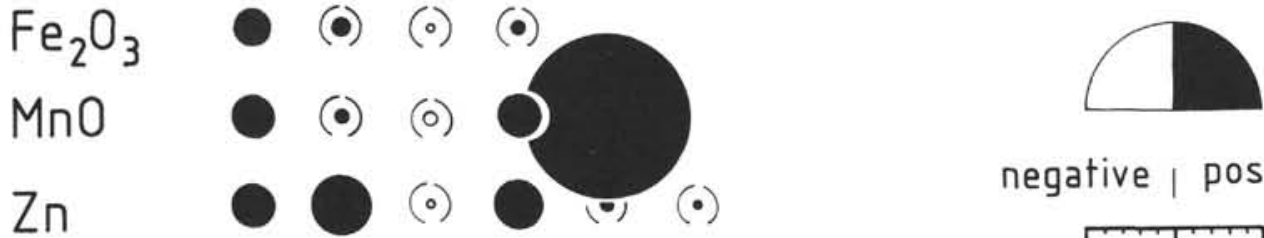

\section{$\mathrm{P}_{2} \mathrm{O}_{5}$

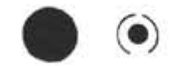

$(\bullet)$

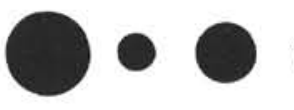

$(\bullet)$

V

CaO

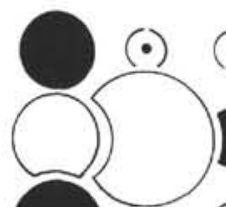

(o)

(०)

(O)

0

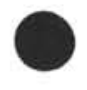

negative | positive correlation

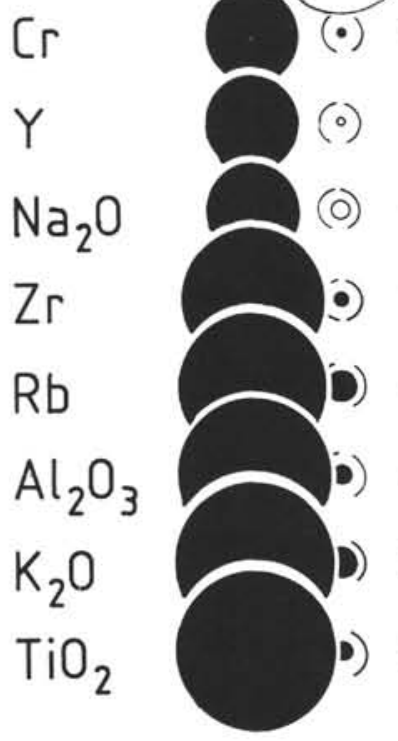

(•)<smiles>C1CCCC2=C(CC1)CCC1CCCC1CC2</smiles><smiles>c1ccccc1</smiles>

$|r|=0 \quad 0.5 \quad 1$

$(\bullet)=$ not significant

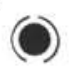

(•)

(o)

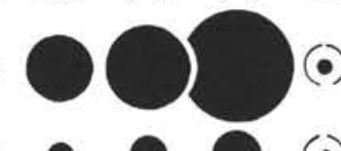

$0^{\circ} \bigcirc$

(•)

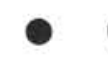

(0)
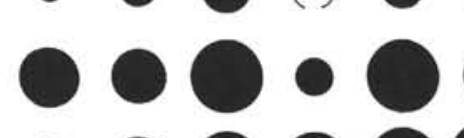

0000

(O)
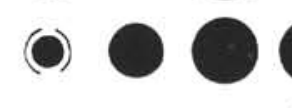

(o)

(•)

(0)
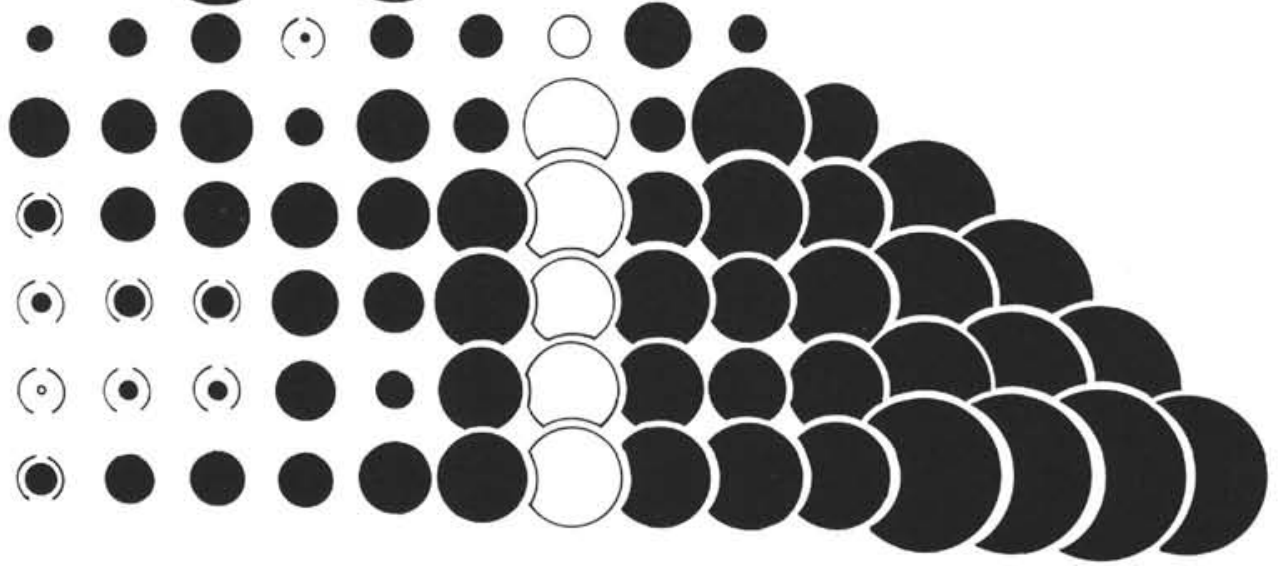

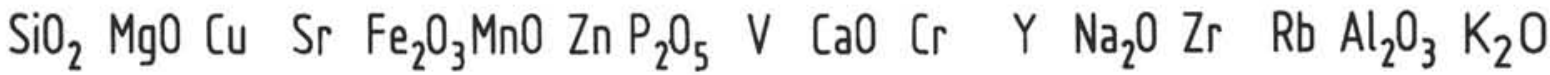

Figure 14. Correlation matrix derived from the chemical analysis of 81 samples from the Wombat Plateau. For further explanations, see text.

reef limestones, they are mainly documented by solution phenomena.

The intensive marine cementation was followed partly by a facies-dependent dissolution (e.g., microkarst) and by mixedwater(?) dolomitization under late meteoric conditions.

Post-depositional (post-Rhaetian) uplift. The major block-tectonic event is of post-Rhaetian, maybe Liassic or Dogger, age. It caused local uplift and a northward tilting of the Wombat Plateau horst (Fig. 16), which was then strongly eroded and became an area of nondeposition.

There is evidence for the post-depositional uplift and subaerial erosion of the Wombat Plateau during the Jurassic. This evidence includes (1) regional geological and seismic data, (2) diagenetic overprinting, and (3) the composition of the lower Neocomian transgressive sand at Site 761.

Seismic and regional geological evidence. Such evidence (Dumont, this volume; Exon et al., 1982; Veevers, 1988; Williamson et al., 1989; von Rad et al., in press) shows the existence of an erosional post-rift unconformity that caps the Late Triassic earlyrift sequences of the Wombat Plateau which is overlain by a thin Cretaceous to Cenozoic (hemi-)pelagic sequence.

Diagenetic evidence. This chapter does not provide a conclusive answer as to subaerial exposure from the diagenetic point of view. However, the syn-Rhaetian diagenetic features were strongly overprinted by a later (Jurassic) phase of diagenesis, which affected the entire Upper Triassic sediment pile. 


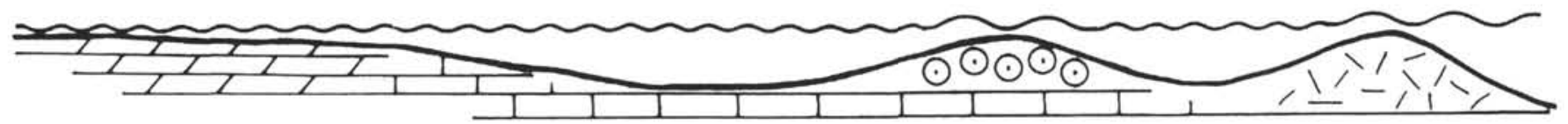

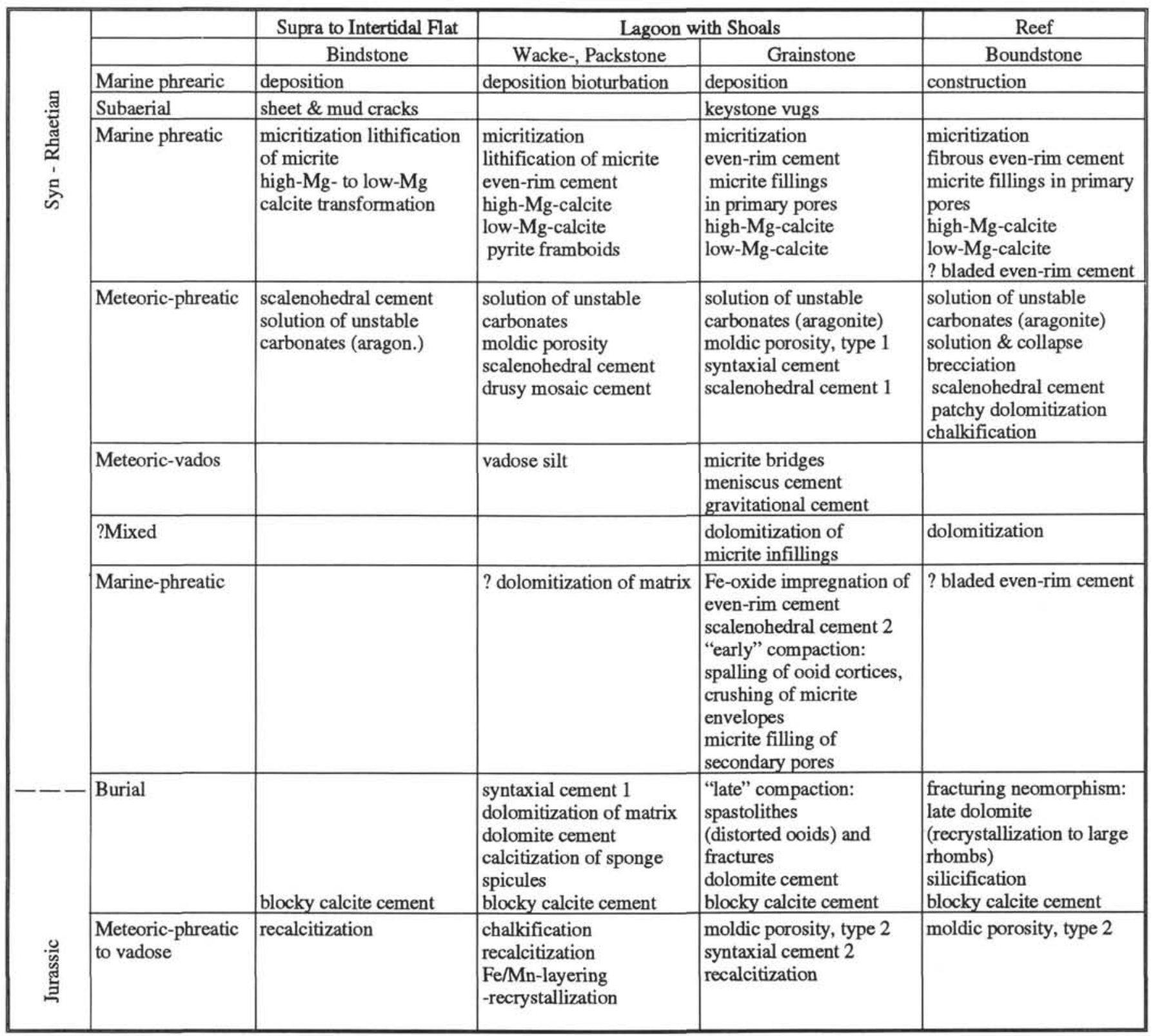

Figure 15. Diagenetic model. Each facies type shows different diagenetic features and pathways according to its primary composition (mineralogy and chemistry) and fabric (porosity and permeability).

We identified an upward increase in moldic porosity and dedolomitization features in the sections of Sites 761 and 764 , due to the presumably upward increase of freshwater influence.

The iron-oxide laminations at Site 764 indicate a reduction/oxidation boundary and was probably the result of a fossil groundwater horizon.

Presumably, the Wombat Plateau was uplifted to just above sea level. Indicators of an intensive paleokarst are lacking.
Evidence from the overlying lower Neocomian transgressive sand. The major erosional post-rift unconformity is overlain at the northern Wombat Plateau by a condensed transgressive series starting with a Berriasian/Valanginian belemnite-bearing sand at Site 761 (see von Rad et al., this volume; Thurow and von Rad, this volume). This "sand" contains abundant Fe-stained quartz, unstable feldspar (including K-feldspar), and volcanic rock fragments derived from the Rhaetian-Liassic volcanics, exposed at the 


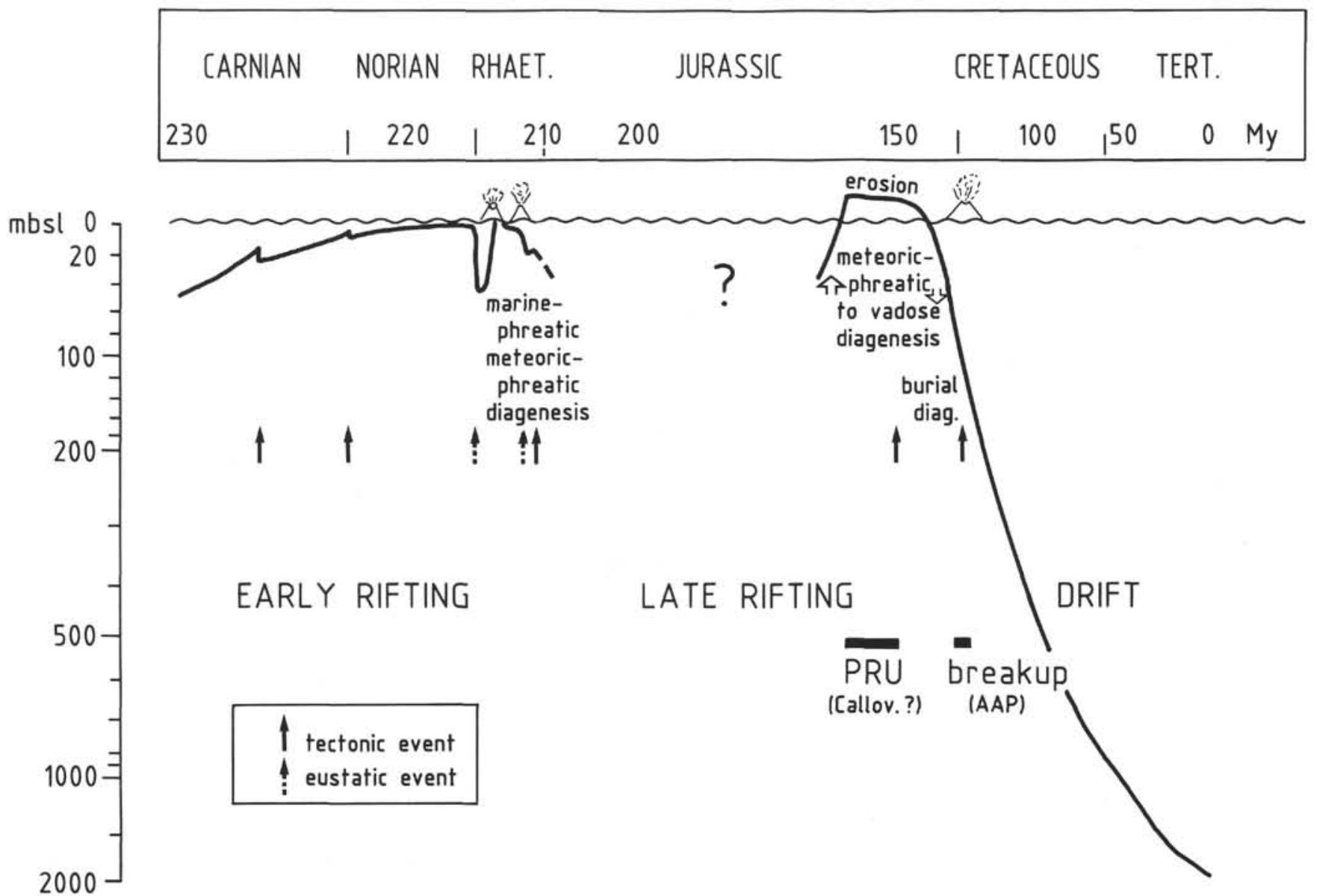

Figure 16. Tectonic, eustatic, subsidence, geological, and diagenetic history of the Wombat Plateau during the past $230 \mathrm{Ma}$. PRU = post-rift unconformity, AAP $=$ Argo Abyssal Plain, $\mathrm{mbsl}=$ meters below sea level.

northern Wombat Plateau margin (von Rad and Exon, 1983). The terrigenous material (mainly quartz) was probably reworked from the Carnian to Norian siliciclastic sediments during the transgression, as was a crinoid calice of middle Jurassic to early Neocomian age found within the belemnite sand (Kristan-Tollmann, pers. comm., 1990). The immaturity and heterogeneity of this transgressive sand suggests the existence of an emerged Wombat island at the Jurassic/Cretaceous boundary (R. Boyd, pers. comm., 1990). Because of continuing erosion at the current-swept northern rim of Wombat Plateau, the Rhaetian of Site 764 is directly overlain by Campanian nannofossil chalk and not, as at Site 761 , by the Neocomian juvenile-ocean facies.

\section{ACKNOWLEDGMENTS}

We are grateful to the Deutsche Forschungsgemeinschaft (Bonn) for its financial support of the ODP research project (Ra 191/10). We thank M. Sarti, Cosenza, and T. Dumont, Grenoble, for sharing the European thin-section collection with us.

H. Rösch, Hannover, provided X-ray diffraction analyses, J. Lodziak and D. Requard, Hannover, the XRF analyses. E. Knickrehm, Hannover, helped with the SEM/EDX analysis and U. Zinkernagel, Bochum, with the cathodoluminescence analysis. $\mathrm{H}$. Karmann, Hannover, provided drafting assistance. We are very grateful for critical comments by S. O'Connell (Middletown, MA) and for reviews by R. K. Matthews (Providence, RI) and R. J. Stanton (College Station, TX).

\section{REFERENCES}

Baker, P. A., and Kastner, M., 1981. Constraints on the formation of sedimentary dolomites. Science, 213:214-216.

Brandner, R., 1984. Meeresspiegelschwankungen und Tektonik in der Trias der NW-Tethys. Jahrb. Geol. Bundesanst. Austria, 126:435475.

Choquette, P. W., and Pray, L. C., 1970. Geologic nomenclature and classification of porosity in sedimentary carbonates. AAPG Bull., $54: 207-250$

Constanz, R. B., 1986. The primary surface area of corals and variations in their susceptibility to diagenesis. In Schroeder, J. H., and Purser, B. H. (Eds.), Reef Diagenesis: Berlin (Springer), 53-76.

Domingo, R.Ma.A., 1989. Facies and diagenetic aspects of a Miocene carbonate sequence, Santan A-1XA well, Visayas, Philippines. Geol. Jahrb., 70:277-301.

Dullo, W.-C., 1986. Variations in diagenetic sequences: an example from Pleistocene coral reefs, Red Sea, Saudi Arabia. In Schroeder, H. H., and Purser, B. H. (Eds.), Reef Diagenesis: Berlin (Springer), 77-90.

Dunham, R. J., 1962. Classification of carbonate rocks according to depositional texture. In Ham, W. E. (Ed.), Classification of Carbonate Rocks: AAPG Mem., 108-121.

Einsele, G., 1982. General remarks about the nature, occurrence, and recognition of cyclic sequences (periodites). In Einsele, G., and Seilacher, A. (Eds.), Cyclic and Event Stratification: Berlin (Springer), 3-7.

Enos, P., 1986. Diagenesis of Mid-Cretaceous Rudist reefs, Valles Platform, Mexico. In Schroeder, J. H., and Purser, B. H. (Eds.), Reef Diagenesis: Berlin (Springer), 160-187. 
Evamy, B. D., 1967. Dedolomitization and the development of rhombohedral pores in limestones. J. Sediment. Petrol., 37:1204-1215.

Exon, N. F., von Rad, U., and von Stackelberg, U., 1982. The geological development of the passive margins of the Exmouth Plateau off northwest Australia. Mar. Geol., 47:131-152.

Exon, N. F., Williamson, P. E., von Rad, U., Haq, B. U., O'Connell, S., 1989. Ocean drilling finds Triassic reef play off NW Australia. Oil \& Gas J., 87:46-52.

Fabricius, F. H., 1974. Die stratigraphische Stellung der Rhät-Fazies. Schriftenr. Erdwiss. Komm. Österr. Akad. Wiss., 2:87-92.

Fagerstrom, J. A., 1987. The Evolution of Reef Communities: New York (Wiley).

Fischer, A. G., 1964. The Lofer cyclothems of the alpine Triassic. Bull. Geol. Surv. Kansas, 169:107-149.

Flügel, E., 1982. Microfacies Analysis of Limestones: New York (Springer-Verlag).

Folk, R. L., 1959. Practical petrographical classification of limestones. AAPG Bull., 43:1-38.

Folk, R. L., 1962. Spectral subdivision of limestone types. In Ham, W. E. (Ed.), Classification of Carbonate Rocks. AAPG Mem., 1:62-68.

Gradstein, F. M., Gibling, M. R., Jansa, L. F., Kaminski, M. A., Ogg, J. G., Sarti, M., Thurow, J. W., von Rad, U., and Westermann, G.E.G., 1989. Mesozoic stratigraphy of Thakkhola, Central Nepal. Lost Ocean Expedition, Spec. Rep., 1: Halifax, Canada (Seaboard Printing).

Haq, B. U., Hardenbol, J., and Vail, P. R., 1987. Chronology of fluctuating sea levels since the Triassic. Science, 235:1156-1167.

Haq, B. U., von Rad, U., O'Connell, S., et al., 1990. Proc. ODP, Init. Repts., 122: College Station, TX (Ocean Drilling Program).

Harris, P. M., Halley, R. B., and Lukas, K. J., 1979. Endolith microborings and their preservation in Holocene-Pleistocene (Bahamas-Florida) ooids. Geology, 7:216-220.

Henrich, R., and Zankl, H., 1986. Diagenesis of Upper Triassic Wetterstein reefs of the Bavarian alps. In Schroeder, J. H., and Purser, B. H. (Eds.). Reef Diagenesis: Berlin (Springer), 245-268.

Hohenegger, J., and Piller, W., 1975. Diagenetische Veränderungen bei obertriadischen Foraminiferen. Neues. Jahrb. Geol. Paläontol. Abh., 146:263-297.

James, N. P., 1974. Diagenesis of scleractinian corals in the subaerial vadose environment. J. Paleontol., 48:785-799.

Kendall, C.G.St.C., and Schlager, W., 1981. Carbonates and relative changes in sea level. Mar. Geol, , 44:181-212.

Kerans, C., Hurley, N. F., and Playford, P. E., 1986. Marine diagenesis in Devonian reef complexes of the Canning Basin, Western Australia. In Schroeder, J. H., and Purser, B. H. (Eds.), Reef Diagenesis: Berlin (Springer), 357-380.

Koch, R., Ogorelec, B., and Orehek, S., 1989. Microfacies and diagenesis of Lower and Middle Cretaceous Carbonate rocks of NW Yugoslavia (Slovenia, Trnovo area). Facies, 21:136-169.

Kristan-Tollmann, E., 1986. Beobachtungen zur Trias am Südostende der Tethys-Papua/Neuguinea, Australien, Neuseeland. Neues. Jahrb. Geol. Paläontol. Monatsh., 1986:201-222.

Longman, M. W., 1980. Carbonate diagenetic textures from nearsurface diagenetic environments. AAPG Bull., 64:461-487.

Machel, H. G., 1985. Cathodoluminescence in calcite and dolomite and its chemical interpretation. Geosci. Can., 12:139-147.

Moore, C. H., 1989. Carbonate Diagenesis and Porosity: Amsterdam (Elsevier).

Muller, A., Parting, H., and Thorez, J., 1973. Caractères sédimentologiques et minéralogiques des couches de passage du Trias au Lias sur la bordure nord-est du Bassin de Paris. Ann. Soc. Geol. Belg., 96:671-701.

Mussmann, W. J., Montanez, I. P., and Read, F. J., 1988. Ordovician Knox paleokarst unconformity, Appalachians. In James, N. P., and Choquette, P. W. (Eds.), Paleokarst: Berlin (Springer), 211-228.

Pearson, B. J., and Shinn, E. A., 1985. Cement distribution and carbonate mineral stabilization in Pleistocene limestones of Hogsty Reef, Bahamas. In Schneidermann, N., and Harris, P. M. (Eds.), Carbonate Cements. Spec. Publ. Soc. Econ. Paleontol. Mineral., 36:153-168.

Piller, W., 1976. Fazies und Lithostratigraphie des gebankten Dachsteinkalkes (Obertrias) am Nordrand des Toten Gebirges (S'Grünau/ Almtal, Oberösterreich). Mitt. Ges. Geol. Bergbaustud. Österr., 23:113-152.
Purser, B. H., and Schroeder, J. H., 1986. The diagenesis of reefs: a brief review of our present understanding. In Schroeder, J. H., and Purser, B. H. (Eds.), Reef Diagenesis: Berlin (Springer), 424-446.

Quilty, P. G., 1990. Triassic and Jurassic foraminiferal faunas, northern Exmouth Plateau, eastern Indian Ocean. J. Foraminiferal Res. 20:349-367.

Röhl, U., Dumont, T., von Rad, U., Zaninetti, L., 1991. The Upper Triassic carbonate platform off NW Australia (ODP Leg 122): reefs and lagoons of Tethyan facies and diagenetic evolution. Facies, $25: 211-252$.

Roux, M., Bourseau, J. P., Bas, T., Dumont, T., De Graciansky, P. G., Lemoine, M., and Rudkiewicz, J. L., 1988. Bathymetric evolution of the Tethyan margin in the Western Alps (data from stalked crinoids) a reappraisal of eustatism problems during the Jurassic. Bull. Soc. Geol. Fr., IV:633-641.

Roy, S., 1981. Manganese Deposits: London (Academic Press).

Russell, M. J., and Ogehenejobo, M.J.O., 1984. Experience with a new petrophysical evaluation tool-the gamma-ray spectroscopy tool (GST): 8th Ann. Inter. SPE Nigeria Sect. Conf., paper SPE-LS-126.

Sarg, J. F., 1988. Carbonate sequence stratigraphy. Spec. Publ. Soc. Econ. Paleontol. Mineral., 42:155-181.

Sass, E., and Katz, A., 1982. The origin of platform dolomites: new evidence. Am. J. Sci., 282:1184-1213.

Scaturo, D. M., Strobel, J. S., Kendall, C.G.St.C., Wendte, J. C., Biswas, G., Bezdek, J., and Cannon, R., 1989. Judy Creek: a case study for a two-dimensional, sediment deposition simulation. Spec. Publ. Soc. Econ. Paleontol. Mineral., 44:63-76.

Schäfer, P., 1979. Fazielle Entwicklung und palökologische Zonierung zweier obertriasischer Riffstrukturen in den nördlichen Kalkalpen (“Oberrhät"-Riff-Kalke, Salzburg). Facies, 1:3-245.

Schäfer, P., and Senowbari-Daryan, B., 1981. Facies development and paleoecologic zonation of four Upper Triassic patch-reefs, northern Calcareous Alps near Salzburg, Austria. Spec. Publ. Soc. Econ. Paleontol. Mineral., 30:241-259.

Scholle, P. A., Bebout, D. G., and Moore, C. H. (Eds.), 1983. Carbonate Depositional Environments. AAPG Mem., 33.

Schott, M., 1983. Sedimentation und Diagenese einer absinkenden Karbonatplattform: Rhät und Lias des Brünnstein-Auerbach-Gebietes, Bayerische Kalkalpen. Facies, 9:1-60.

Schroeder, J. H., 1979. Carbonate diagenesis in Quaternary beachrock of Uyombo, Kenya: sequences of process and coexistence of heterogenous products. Geol. Rundsch., 68:894-919.

Senowbari-Daryan, B., 1980. Fazielle und paläontologische Untersuchungen in oberrhätischen Riffen (Feichtenstein- und Gruberriff bei Hintersee, Salzburg, Nördliche Kalkalpen). Facies, 3:1-237.

Shinn, E. A., 1983. Tidal flat environment. In Scholle, P. A., Bebout, D. G., and Moore, C. H. (Eds)., Carbonate Depositional Environments. AAPG Mem., 33:171-210.

Stanley, G. D., Jr., 1988. The history of early Mesozoic reef communities: a three-step process. Palaios, 3:170-183.

Stanton, R. J., Jr., and Flügel, E., 1989. Problems with reef models: the Late Triassic Steinplatte "reef" (Northern Alps, Salzburg/Tyrol, Austria). Facies, 20:1-138.

Stinder, T., 1989. Stratigraphie und Lithologie des Rhät (Oberkeuper) im mittleren Niedersachsen (Norddeutschland). Z. Dtsch. Geol. Ges., 140:87-99.

Strasser, A., and Davaud, E., 1986. Formation of Holocene limestone sequences by progradation, cementation and erosion: two examples from the Bahamas. J. Sediment. Petrol., 56:422-428.

Vail, P. R., Mitchum, R. M., Jr., Todd, R. G., Widmier, J. M., Thompson, S. III, Sangree, J. B., Bubb, J. N., and Hatlelid, W. G., 1977. Seismic stratigraphy and global changes in sea level. In Payton, C. E. (Ed.), Seismic Stratigraphy-Applications to Hydrocarbon Exploration: AAPG. Mem., 26:49-212.

Van Wagoner, J. C., Posamentier, H. W., Mitchum, R. M., Vail, P. R., Sarg, J. F., Loutit, T. S., and Hardenbol, J., 1988. An overview of the fundamentals of sequence stratigraphy and key definitions. In Wilgus, C., et al., (Eds.), Sea-level Change: An Integrated Approach: (Soc. Econ. Paleontol. Mineral. Spec. Publ.), 42:39-46.

Veevers, J. J., 1988. Morphotectonics of Australia's northwestern margin. In Purcell, P. G., and R. R. (Eds.), The North West Shelf Australia. Proc. Petrol. Expl. Soc. Austr. Symp., 19-27. 
von Rad, U., and Exon, N. F., 1983. Mesozoic-Cenozoic sedimentary and volcanic evolution of the starved passive continental margin off northwest Australia. In Watkins, J. S., and Drake, C. L. (Eds.), Studies in Continental Margin Geology: AAPG Mem., 34:253-281.

von Rad, U., Schott, M., Exon, N. F., Mutterlose, J., Quilty, P. G., and Thurow, J., 1990. Mesozoic sedimentary and volcanic rocks dredged from the northern Exmouth Plateau: petrography and microfacies. BMR J. Aust. Geol. Geophys., 11:449-472.

von Rad, U., Thurow, J., Haq, B. U., Gradstein, F., Ludden, J., et al., 1989. Triassic to Cenozoic evolution of the N.W. Australian Margin and the birth of the Indian Ocean (Preliminary results of ODP Legs 122 and 123). Geol. Rundsch., 78:1189-1210.

von Stackelberg, U., Exon, N. F., von Rad, U., Quilty, P., Shafik, S., Beiersdorf, H., Seibertz, E., and Veevers, J. J., 1980. Geology of the Exmouth and Wallaby Plateaus off northwest Australia: sampling of seismic sequences. BMR J. Aust. Geol. Geophys., 5:113-140.
Walkden, G. M., and Berry, J. R., 1984. Syntaxial overgrowth in muddy crinoidal limestones: cathodoluminescence sheds new light on an old problem. Sedimentology, 31:251-267.

Walker, K. R., and Alberstadt, L. P., 1975. Ecological succession as an aspect of structure in fossil communities. Paleobiology, 1:238-257.

Williamson, P. E., Exon, N. F., Haq, B. U., von Rad, U., O'Connell, S., and Leg 122 Shipboard Scientific Party, 1989. A Northwest Shelf Triassic reef play: results from ODP Leg 122. APEA J., 29:328-344.

Wilson, J. L., 1982. Carbonate Facies in Geology: New York (Wiley).

Zankl, H., 1971. Upper Triassic facies in the Northern Limestone Alps. In Müller, G. (Ed.), Sedimentology of Parts of Central Europe, Guide Book: Frankfurt (Kramer), 147-185.

Date of initial receipt: 14 May 1990

Date of acceptance: 10 December 1990

Ms 122B-146 


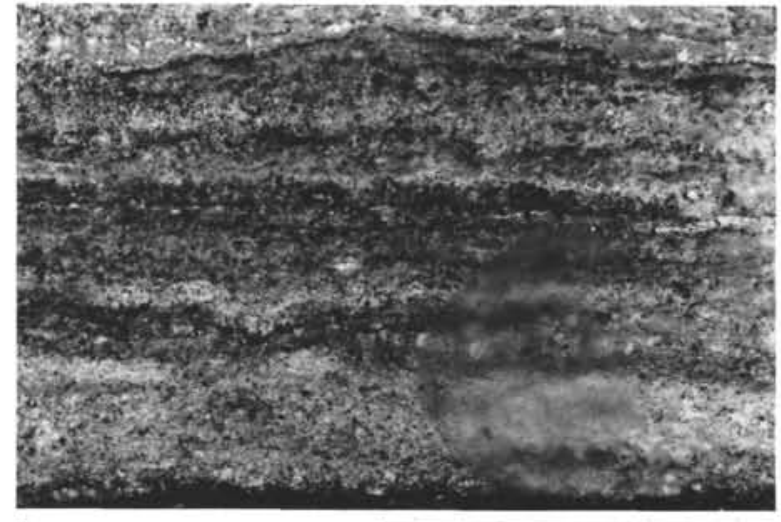

1

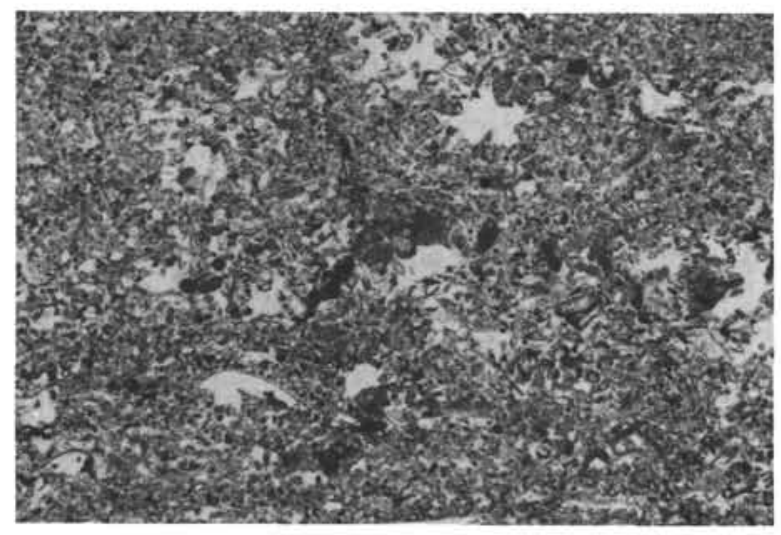

3



5

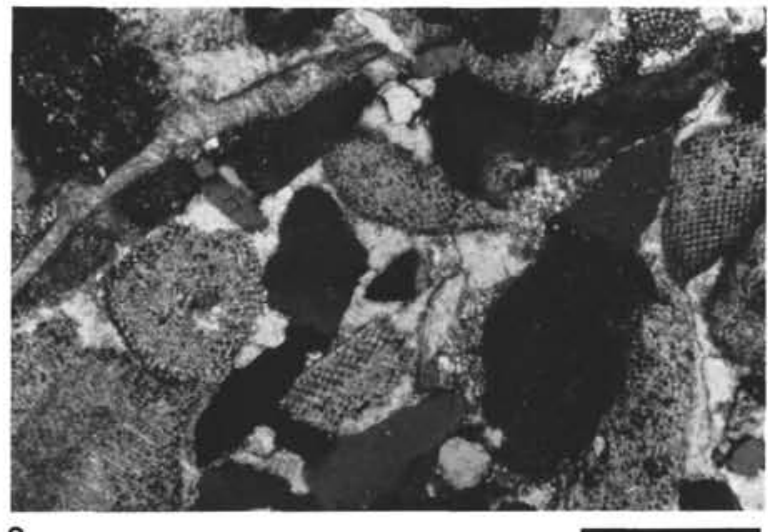

2

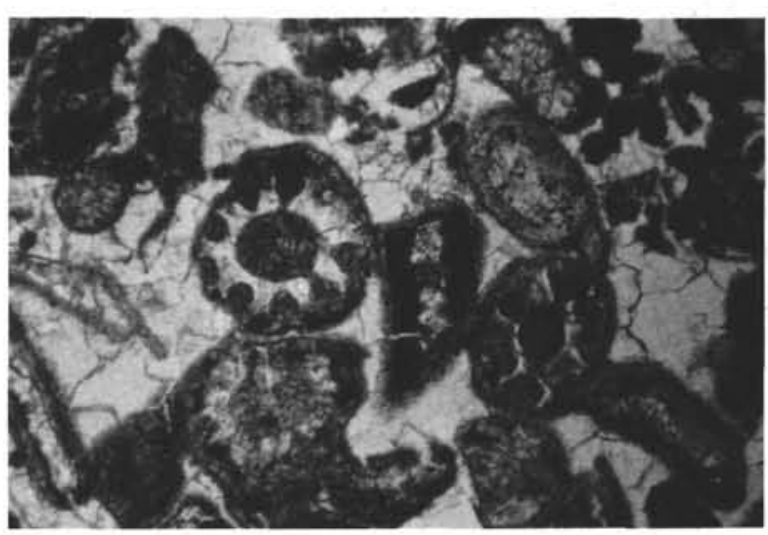

4

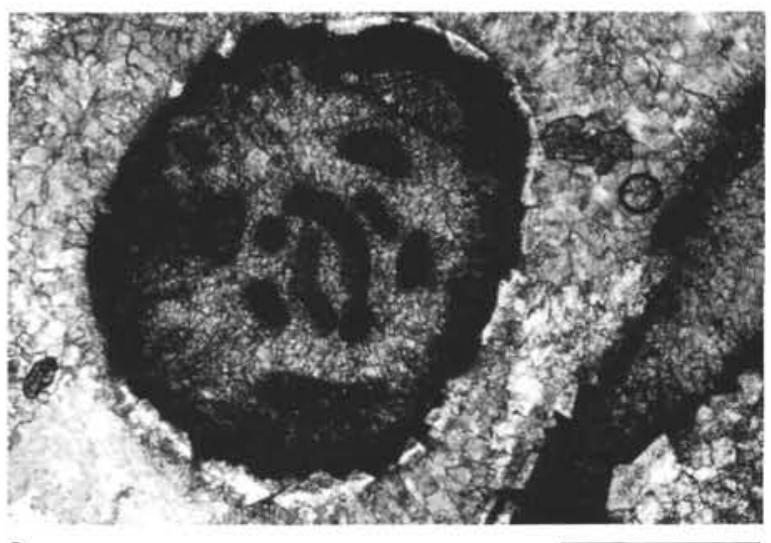

6

Plate 1. Microfacies types. 1. Algal bindstone, MFT 23, biolithite facies; Sample 122-761B-33X-1, 40-41 cm (scale bar =1 cm). 2. Echinodermal pack- to grainstone, MFT 11, crinoid facies (open marine); sample RS56-DR04I $(\mathrm{scale}$ bar $=0.5 \mathrm{~cm}$ ). 3. Peloidal grainstone with keystone vugs, MFT 21, carbonate shoal facies; Sample 122-761C-12R-1, 52-55 cm (scale bar $=0.5 \mathrm{~cm})$. 4. Dasycladacean grainstone, MFT 19, transition shoal facies to calcareous algae facies; Sample 122-760B-20R-CC, $16-18 \mathrm{~cm}$ (scale bar $=300 \mu \mathrm{m})$. 5. Oolitic grainstone, MFT 17, with large calcareous algae fragment, oolitic/oncolitic shoal facies; Sample $122-761 \mathrm{C}-12 \mathrm{R}-1,12-16 \mathrm{~cm}$ (scale bar $=1000 \mu \mathrm{m}$ ). 6. Foraminiferal grainstone, MFT 15 , recrystallized Aulotortus friedli. Even-rim cement (possibly primary high-Mg-calcite) was selectively dolomitized. Sample 122-759B-7R-2, 106-109 $\mathrm{cm}$ (scale bar $=500 \mu \mathrm{m}$ ). 




1

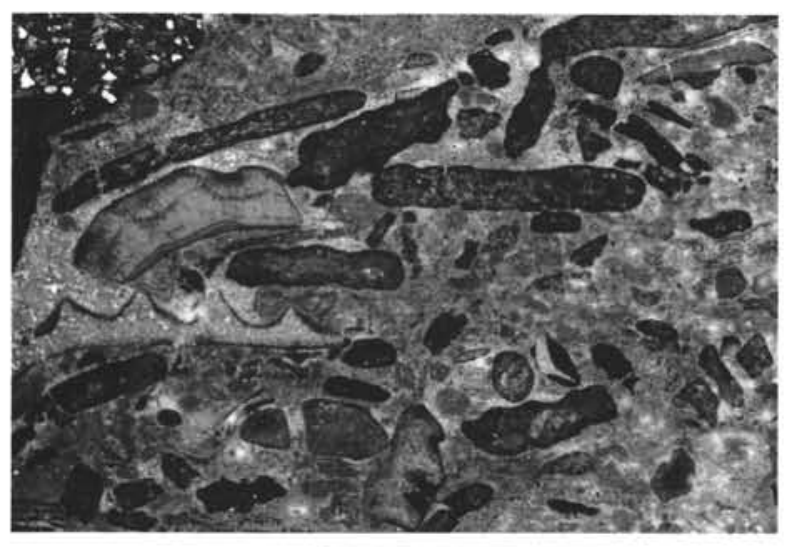

3

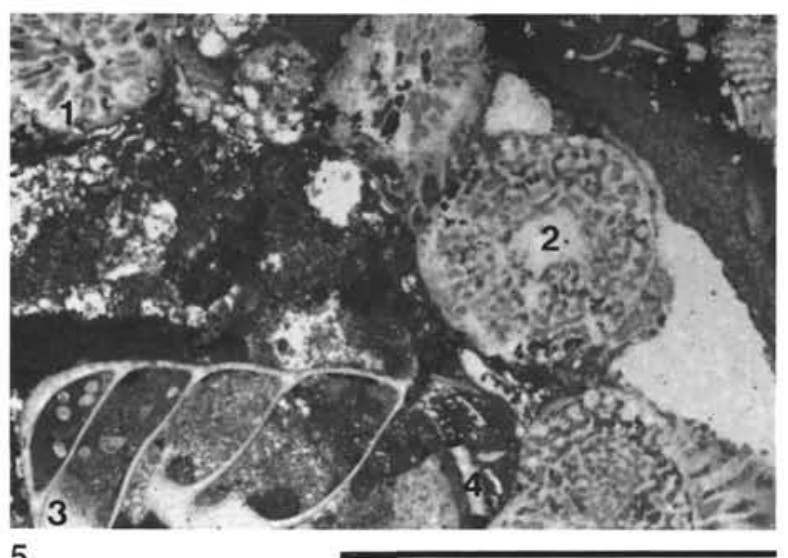



2



4

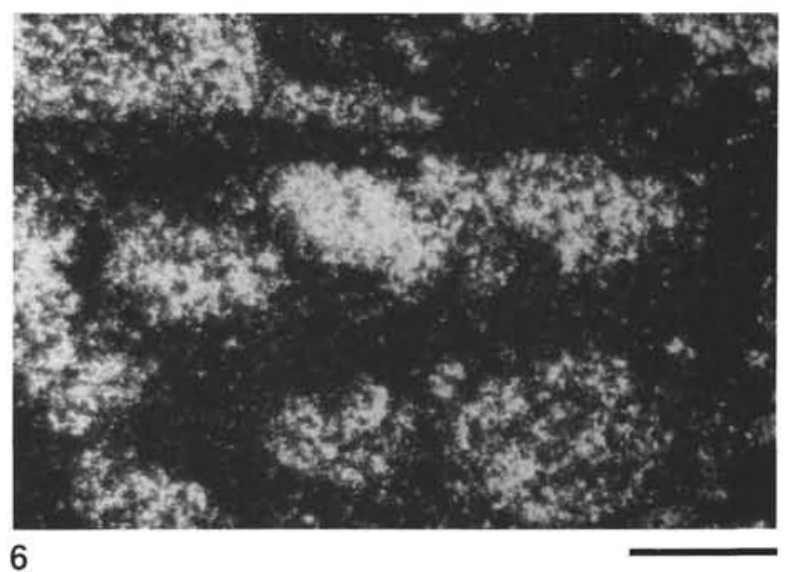

Plate 2. Microfacies types. 1. Oncolitic grainstone, MFT 18, shoal facies; peloids, pelecypod shells, and normal ooids intercalated with large oncoids; Sample 122-760B-17R-2, 15-17 cm (scale bar $=1 \mathrm{~cm}$ ). 2. Skeletal rudstone, MFT 22, with large fragments of pelecypods (coated grains), echinoderms, foraminifers, serpulids, and some calcisponge fragments, reefal debris facies; Sample 122-764B-12R-1, 43-46 cm $(\mathrm{scale}$ bar $=1 \mathrm{~cm}) .3$. Codiacean grainstone, MFT 20, transition facies shoal/lagoon. Imbricated elongated codiacean fragments, peloids, and pelecypod fragments form a grain-supported fabric; Sample 122-760B-21R-1, 120-123 cm (scale bar =1 cm). 4. Coral boundstone (MFT 25) with bioclastic-peloidal grainstone (cavity filling), corals of Astraeomorpha-type, biolithite facies; Sample 122-764B-14R-CC, $2-5 \mathrm{~cm}$ (scale bar $=1 \mathrm{~cm}$ ). 5. Bafflestone with Thecosmilia-type corals (1), calcisponge fragments (2), gastropod with ostracode-bearing micritic filling (3), brachiopod shell (4), echinoderm debris; MFT 24, biolithite facies; Sample 122-764B-24R-CC, $1-4 \mathrm{~cm}$ (scale bar $=0.5 \mathrm{~cm}$ ). 6. Bioturbated wackestone, MFT 2, recrystallized, detritus-mud facies; Sample 122-764A-8R-1, 103-106 $\mathrm{cm}($ scale bar $=1000 \mu \mathrm{m})$. 


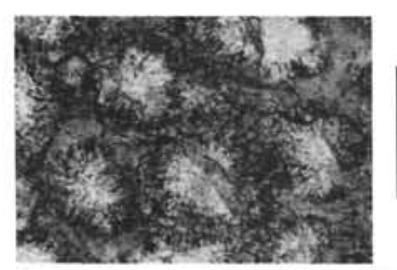

$1 \mathrm{a}$
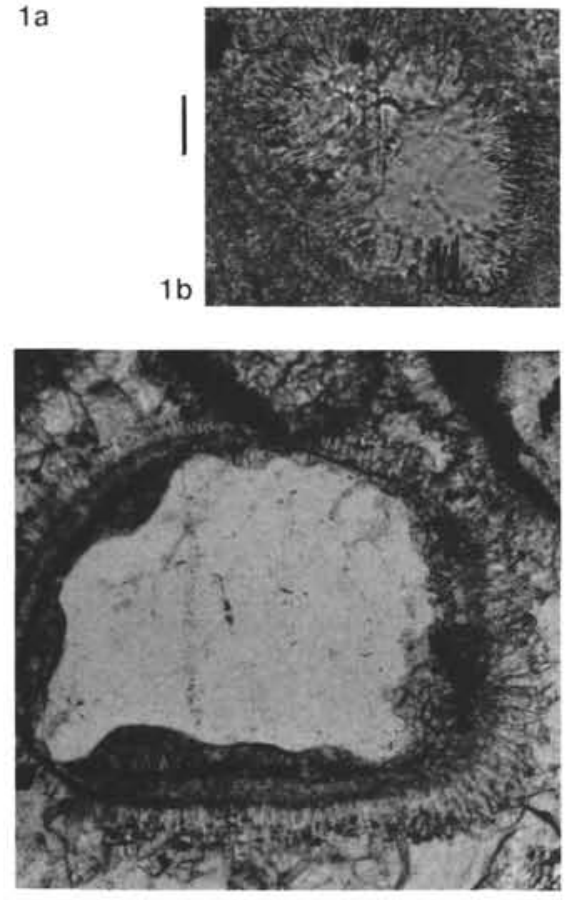

4



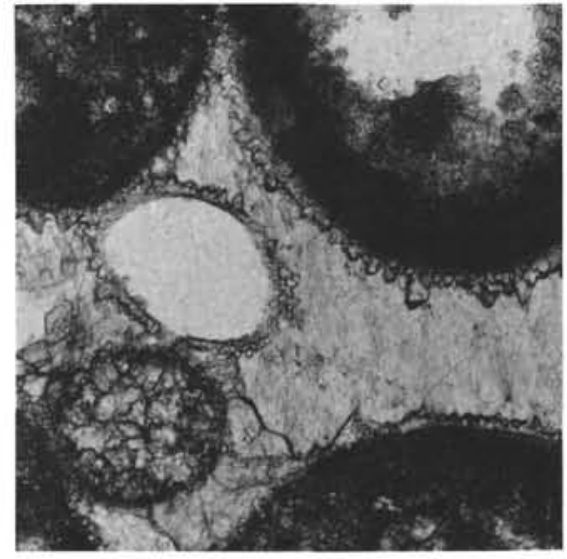

2

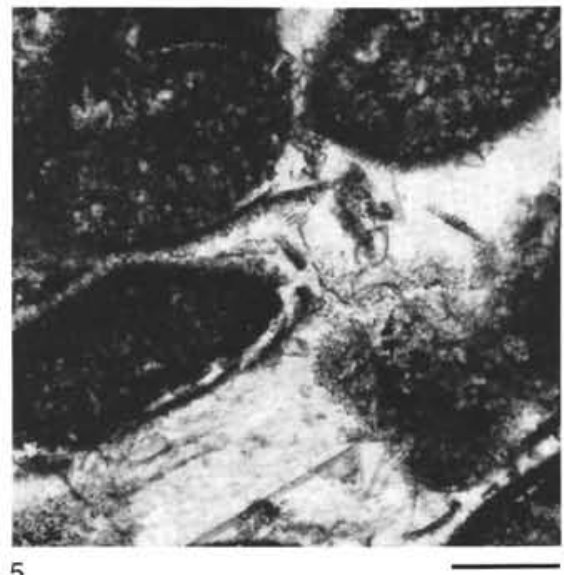

5

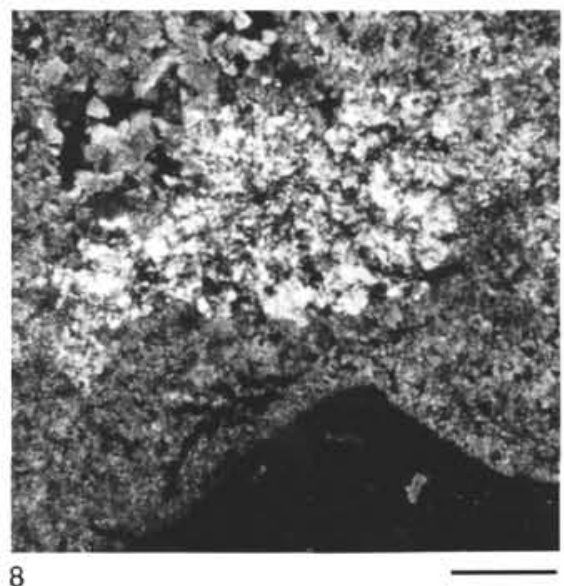

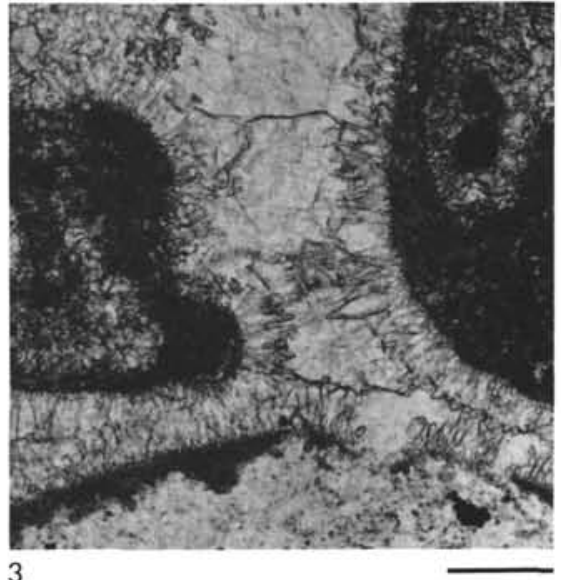

3

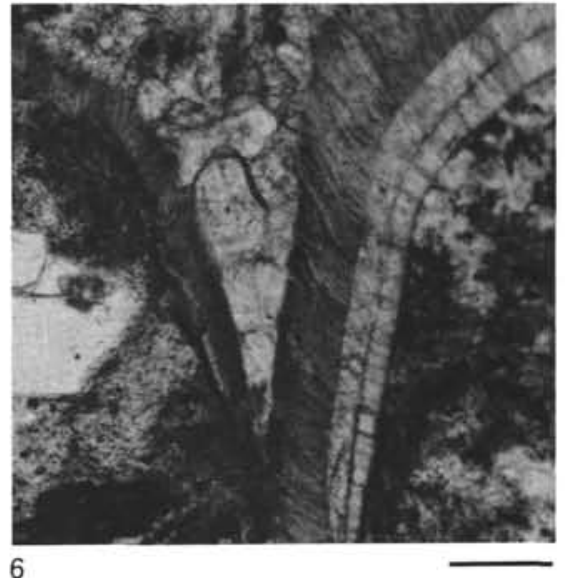

6

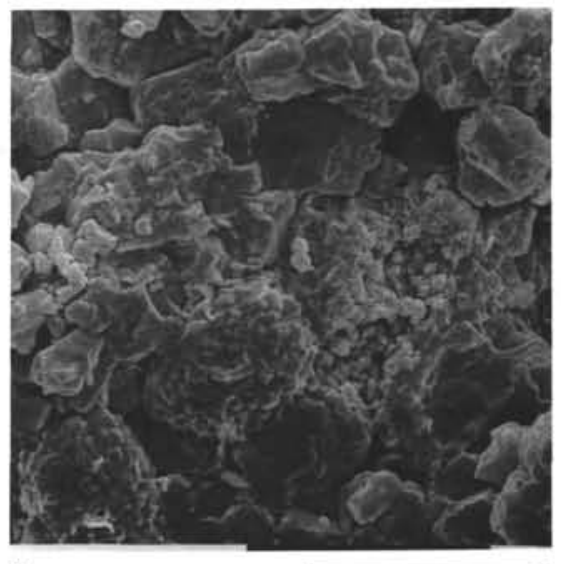

9

Plate 3. Diagenesis. Cements, silicification, and framboidal pyrite. 1. Acicular even-rim cement within coral, crystal morphology indicates the primary aragonitic mineralogy of cements; Sample 122-760B-17R-2, 15-17 cm; (A) overview (scale bar $=50 \mu \mathrm{m}$ ); (B) detail (scale bar $=20 \mu \mathrm{m})$. 2. Equigranular (?recrystallized) even-rim cement, partly scalenohedral, within oolitic grainstone, of meteoric-phreatic origin, oomoldic porosity; Sample 122-760B-15R-1, 59-60 cm (scale bar $=100 \mu \mathrm{m}$ ). 3. Even-rim cement (partly bladed) and blocky calcite cement within grainstone, marine-phreatic to shallow burial; Sample 122-760B-9R-2, 35-38 $\mathrm{cm}($ scale bar $=100 \mu \mathrm{m}) .4$. Even-rim cement, partly bladed, within grainstone, marine phreatic; Sample 122-760B-9R-2, 38-42 cm $(\mathrm{scale}$ bar $=100 \mu \mathrm{m}) .5$. Early compaction. Even-rim cement (marine-phreatic) was split off, blocky (marine-phreatic or shallow burial) calcite healed the remaining pore space; Sample 122-759B-19R-CC, $11-13 \mathrm{~cm}$ (scale bar $=100 \mu \mathrm{m}$ ). 6. Fibrous even-rim cement surrounding volcanic rock fragment and feldspar, primary aragonitic, marine-phreatic; Sample 122-760B-19R-1, 11-13 cm (scale bar $=100 \mu \mathrm{m}$ ). 7. Scalenohedral cement within a secondary (biomoldic) pore, meteoric-phreatic; Sample 122-764B-22R-1, 5-9 cm (scale bar $=100 \mu \mathrm{m}$ ). 8. Silicification (bright areas) within a coral fragment; Sample 122-764B-20R-1, 103-106 cm (scale bar $=1000 \mu \mathrm{m})$. 9. Framboidal pyrite within microspar; Sample 122-760B-16R-1, 137-140 cm; oolitic packstone, MFT $9(\mathrm{scale}$ bar $=10 \mu \mathrm{m})$. 



4

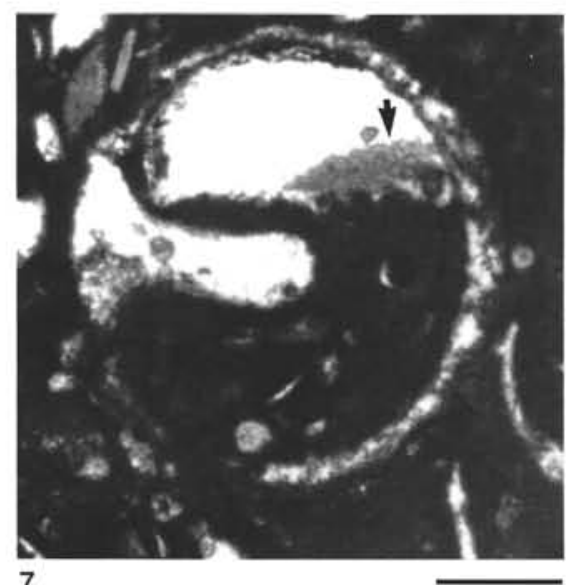

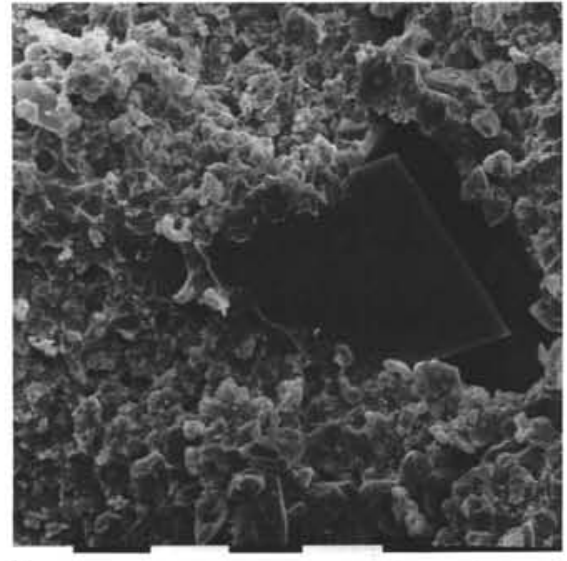

2



5

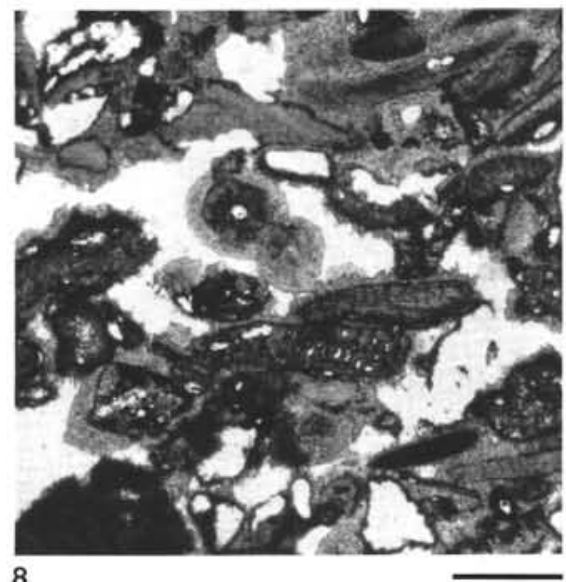

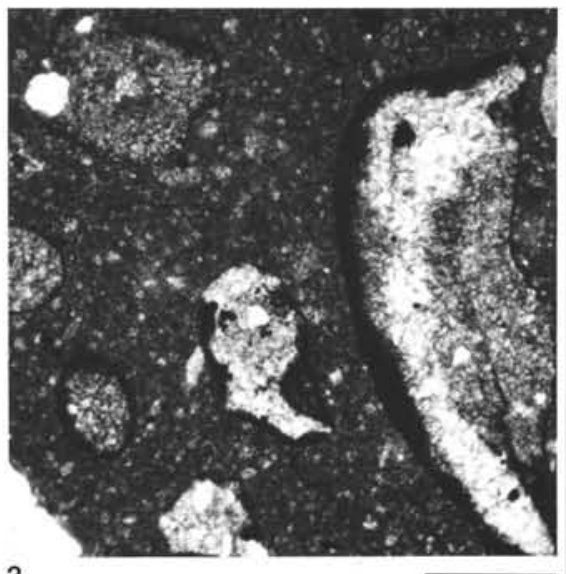

3

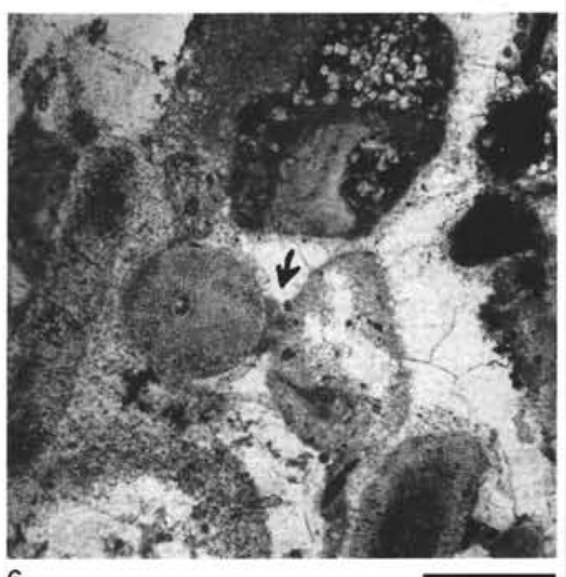

6

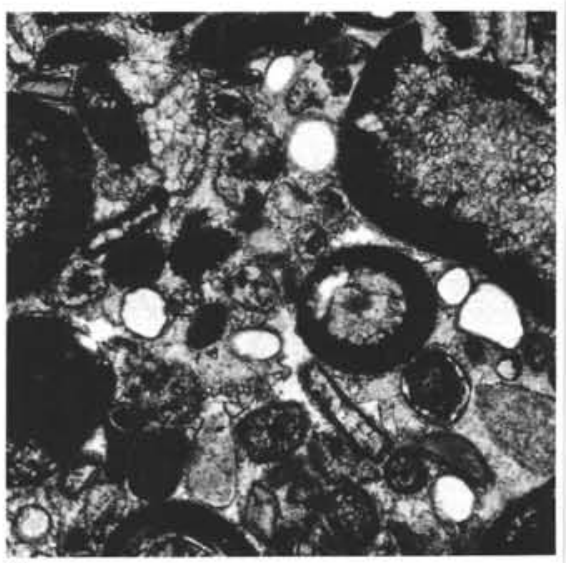

9

Plate 4. Diagenesis. Dolomitization, dedolomitization, meteoric-vadose stage, and secondary porosity. 1. Dolospar with intercrystalline and intracrystalline porosities, cores and outlines of single rhombohedrons are dissolved, meteoric-phreatic overprinting; crossed nicols; Sample 122-764B-22R-1, 13-16 cm (scale $\mathrm{bar}=100 \mu \mathrm{m}) .2$. Dolomitic rhombohedron which grew in secondary pore (mold) within micrite; Sample 122-760B-16R-1, $137-140 \mathrm{~cm}(\mathrm{scale}$ bar $=10 \mu \mathrm{m}) .3$.

Dedolomitized patches within packstone; Sample 122-759B-23R-2, 105-109 cm (scale bar $=500 \mu \mathrm{m}$ ). 4. Dolomitized sediment, calcitic even-rim cement with dogtooth morphology within pore (stained with Alizarin-S), blocky dolomite cement; Sample 122-759B-7R-2, 106-109 cm (scale bar = 500 $\mu$ m). 5. Gravitational cement at the top of a mold indicates meteoric-vadose conditions; Sample 122-764B-26R-1, 13-16 cm (scale bar $=100 \mu \mathrm{m}) .6$. Micritic bridges (arrow) within grainstone; Sample 122-761C-30R-1, 43-46 cm (scale bar $=500 \mu \mathrm{m}) .7$. Vadose silt within gastropod $($ arrow $) ;$ Sample 122-764B-23R-1, 27-30 cm $($ scale bar $=$ $500 \mu \mathrm{m}) .8$. Moldic and interparticle porosity within grainstone; Sample 122-764B-26R-1, 13-16 cm (scale bar $=1000 \mu \mathrm{m}) .9$. Oomoldic porosity, Sample $122-760 \mathrm{~B}-15 \mathrm{R}-2,60-63 \mathrm{~cm}(\mathrm{scale}$ bar $=500 \mu \mathrm{m})$. 


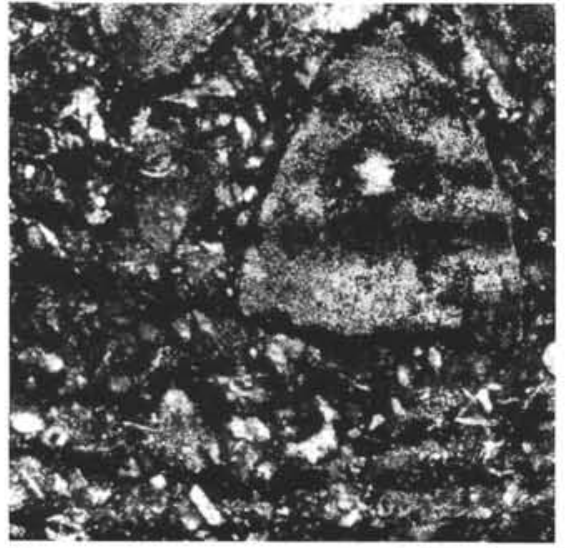

1

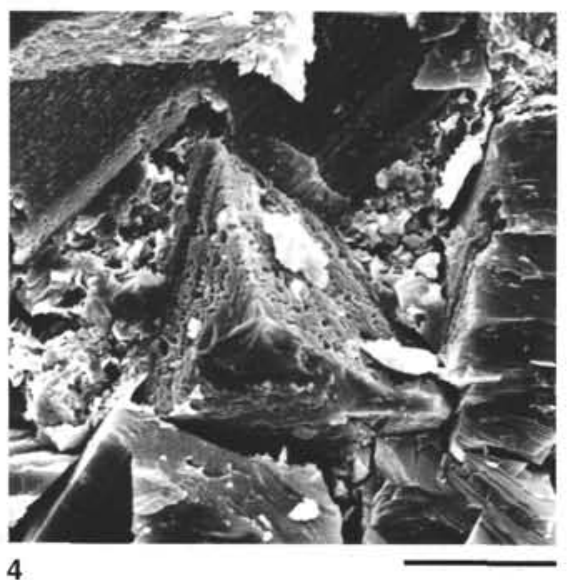

4

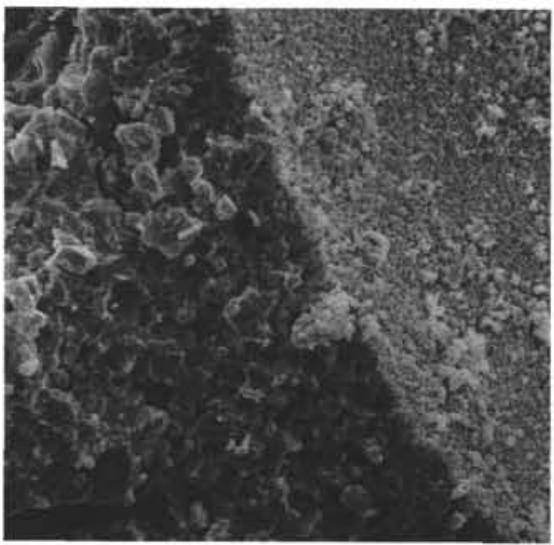

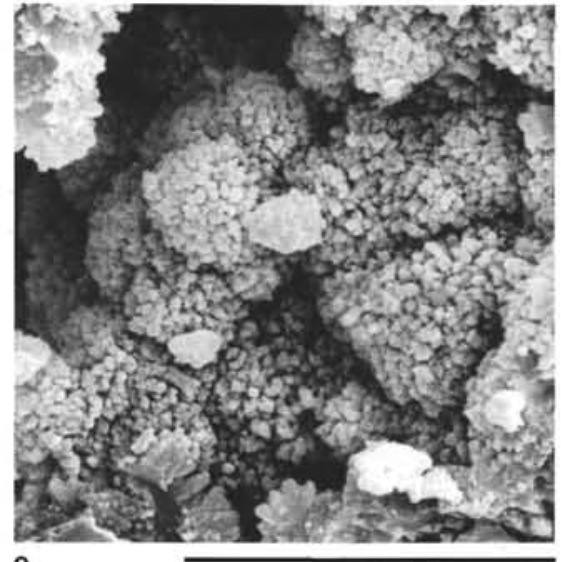

2

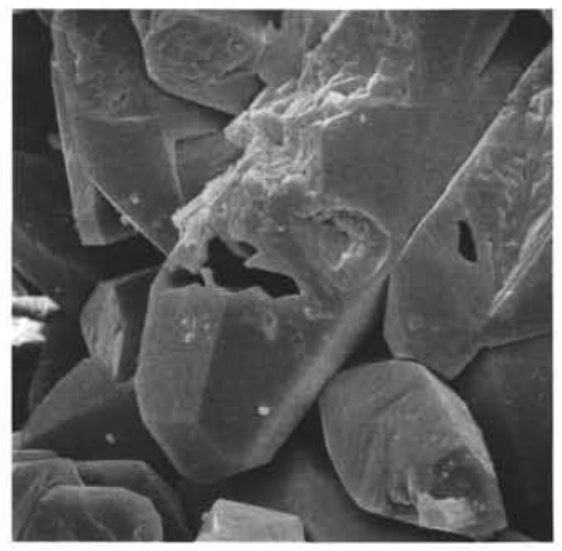

5

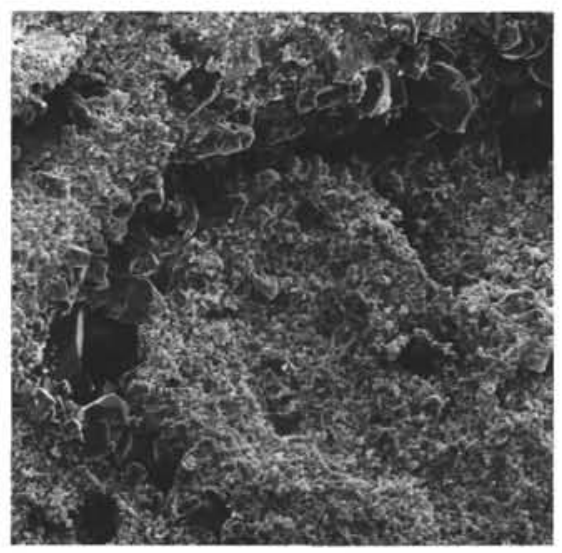

8

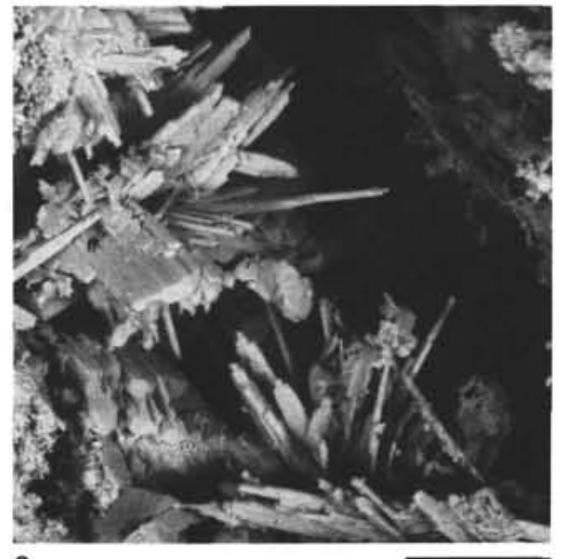

3

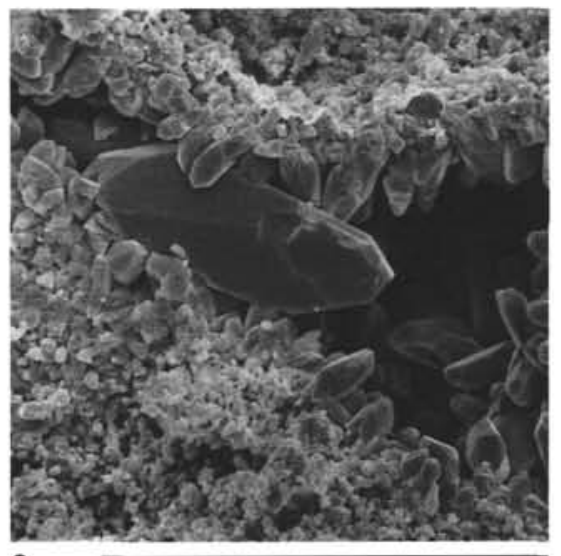

6

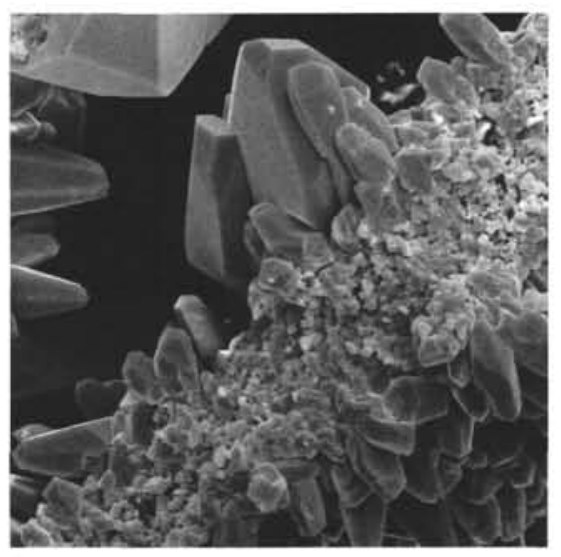

9

Plate 5. Diagenesis. Iron-oxide lamination and porosity. 1. Fe-oxide banding within echinoderm-rich packstone. Note that three laminae cross crinoid fragment, which indicates their late-diagenetic origin $($ scale bar $=500 \mu \mathrm{m}$ ). Sample 122-764A-7R-1, 24-27 cm; 2. SEM, goethite of Fe-oxide lamination; Sample 122-764B-5R-1, 53-56 cm (scale bar $=10 \mu \mathrm{m}) .3$. SEM, rhodochrosite? within goethite interspaces; Sample 122-764B-5R-1, 53-56 cm $(\mathrm{scale}$ bar $=10 \mu \mathrm{m}) .4$. Corrosion of blocky calcite cement, type 1 (see text); Sample 122-759B-7R-2, 106-109 cm; SEM (scale bar $=10 \mu \mathrm{m}) .5$. Corrosion of calcite cement, type 2 (see text); sample 122-764B-30R-1, 6-9 cm (scale equals $10 \mu \mathrm{m}$ ). 6. Cements within moldic porosity, even-rim, scalenohedral and blocky calcite; SEM; Sample 122-764B-23R-1, 27-30 cm (scale bar $=0.1 \mathrm{~mm})$. 7. Contact between peloid and microsparitic matrix; SEM; Sample $122-760 \mathrm{~B}-16 \mathrm{R}-1,137-140 \mathrm{~cm}(\mathrm{scale}$ bar $=$ $10 \mu \mathrm{m})$. 8. Porosity of Triasina hantkeni Mazjon, SEM; Sample 122-761C-21R-CC, 5-6 cm (scale bar $=0.1 \mathrm{~mm})$. 9. Interparticle porosity, even-rim, and scalenoheral cements, SEM; Sample 122-764B-23R-1, 27-30 cm (scale bar = $0.1 \mathrm{~mm}$ ). 